\title{
Intraspecific variation in fossil vertebrate populations: Fossil killifishes (Actinopterygii: Cyprinodontiformes) from the Oligocene of Central Europe
}

\author{
Linda Frey, Erin E. Maxwell, and Marcelo R. Sánchez-Villagra
}

\begin{abstract}
A quantification of intraspecific variation in morphological traits is necessary not only as a basis for taxonomic work but also to understand a basic aspect of evolution. Comparisons among species could reveal differences in plasticity in development among them and even give clues on evolvability. Studies of this kind are rare for extinct species of vertebrates given the lack of adequate samples, but there are notable exceptions. Morphometric and meristic data were collected for three species of fossil killifish in order to quantify intraspecific variation: 67 specimens of Prolebias rhenanus from the Lower Oligocene of Baden-Württemberg, 40 specimens of Pr. stenoura from the Lower Oligocene of Puy-de-Dôme, and 141 specimens of Paralebias cephalotes from the Upper Oligocene of Aix-en-Provence. Nearly identical patterns of intraspecific variation exist between the two species of Prolebias. Fin base lengths and precaudal lengths of the vertebral column are the most variable traits in both species, followed by pterygiophore counts, then other axial length measurements and, least variable, vertebral counts. In neither species was there a significant difference in observed variation between fin and vertebral or meristic and morphometric traits. The only significant correlation shared between the two species is the positive relationship between caudal length of the vertebral column and length of the anal fin base. Precaudal length of the vertebral column is less variable in Paralebias than in Prolebias, while precaudal vertebral count is more variable, in absolute values of the coefficient of variation. Variability in elongation of precaudal vertebrae may be the underlying cause of the absence of correlation between decreased variation in precaudal length of the vertebral column and increased variation in precaudal count in Paralebias cephalotes. We report more similar patterns of variation among Prolebias congeners than between Prolebias and Paralebias, suggesting that trait variability is changing over evolutionary time in this actinopterygian lineage.
\end{abstract}

Linda Frey. Palaeontological Institute and Museum, University of Zurich, Karl-Schmid-Str. 4, CH-8006, Switzerland. linda.frey@pim.uzh.ch

Erin E. Maxwell. Staatliches Museum für Naturkunde, Rosenstein 1, DE-70191 Stuttgart, Germany. erin.maxwell@smns-bw.de

Frey, Linda, Maxwell, Erin E., and Sánchez-Villagra, Marcelo R. 2016. Intraspecific variation in fossil vertebrate populations: Fossil killifishes (Actinopterygii: Cyprinodontiformes) from the Oligocene of Central Europe. Palaeontologia Electronica 19.2.14A: 1-27 palaeo-electronica.org/content/2016/1464-fossil-killifishes-from-europe

Copyright: @ May 2016 Society of Vertebrate Paleontology. This is an open access article distributed under the terms of the Creative Commons Attribution License, which permits unrestricted use, distribution, and reproduction in any medium, provided the original author and source are credited. creativecommons.org/licenses/by/4.0/ 
FREY, MAXWELL, \& SÁNCHEZ-VILLAGRA: FOSSIL KILLIFISHES FROM EUROPE

Marcelo R. Sánchez-Villagra. Palaeontological Institute and Museum, University of Zurich, Karl-SchmidStr. 4, CH-8006, Switzerland. m.sanchez@pim.uzh.ch (corresponding author)

Keywords: Atherinomorpha; morphology; variability; taxonomy; skeleton; modularity

\section{INTRODUCTION}

Macroevolutionary patterns of disparity and diversity are tied to the evolution of variation (Simpson, 1953; Mayr, 1963; Hallgrímsson and Hall, 2005; Webster, 2007, 2014; Hunt, 2007), which can be studied in geological time (Webster, 2007; De Baets et al., 2013). Examination of phenotypic variation within populations is essential for taxonomy because non-consideration of such can lead to taxon over-splitting (Hughes and Labandeira, 1995; Labandeira and Hughes, 1994). To study intraspecific variation in palaeontology, well-preserved and large samples with adequate stratigraphic information are desirable, in order to minimize sampling biases and the effect of timeaveraging (Schaeffer et al., 1972; Bookstein et al., 1978; Petry, 1982; Behrensmeyer, 1982). However, comparisons between variation in extinct and extant populations of invertebrates and vertebrates show that palaeontological samples were not strongly affected by time-averaging (Bell and Legendre, 1987; MacFadden, 1989; Bush et al., 2002; Hunt, 2004a, b). Studies of variation in extinct populations or species are more common when studying invertebrates, such as trilobites (Hughes and Labandeira, 1995; Labandeira and Hughes, 1994; Webster, 2007, 2014; Hopkins, 2011), ammonoids (Hohenegger and Tatzreiter, 1992; Korn and Klug, 2007; Monnet et al., 2010; De Baets et al., 2013), and crinoids (Lane, 1963; Meyer and Ausich, 1997). Among fossil tetrapods, studies on intraspecific variation have been conducted for example for dinosaurs (Raath, 1990; Bever et al., 2011; Foth and Rauhut, 2013), ichthyosaurs (Maxwell, 2012), rodents (Renaud et al., 2006; Lazzari et al., 2010) and horses (MacFadden, 1997). Several studies on variation in extinct populations of fishes have been carried out during the last three decades, mostly concerning microstratigraphic changes in variation of meristic and morphometric characters of different body parts, or phenotypic variation as it relates to taxonomically informative characters (Bell and Haglund, 1982; Bell et al., 1985; Bell and Legendre, 1987; Cloutier, 1997; Smith, 1987; McCune, 1990, 1996; Barton and Wilson, 1999; Micklich and Klappert, 2004; Grande, 2010; Table $1)$.
We chose fossil populations of cyprinodontiforms as a study system in which to examine phenotypic variation in palaeontology. Cyprinodontiformes represents a speciose clade of teleosts, including extant and extinct taxa (approximately 1200 species, 125 genera) that occur in freshwater and brackish waters of Europe, Africa, and Asia (Nelson, 2006; Costa, 2012). The skeletons of many species of Oligocene and Miocene killifishes of Europe are well-preserved and articulated, present in many localities in very high numbers (Gaudant, 2013). As such, they are a good subject for studies of phenotypic variation. Fossil populations of valenciids such as Prolebias rhenanus Gaudant, 1981a and Pr. stenoura Sauvage, 1874 and of poeciliids such as Paralebias cephalotes (Agassiz, 1839) in particular are represented by large numbers of individuals from restricted stratigraphic and geographic intervals in France and Germany (e.g., Pa. cephalotes: Figure 1).

Studies of variation in extant killifishes can provide the bases for evaluation of fossils. Recent populations of closely-related species are preferred study objects for the examination of morphological differentiation within and among populations because of their occurrence in different environments and their separation by natural barriers (e.g., Hubbs and Miller, 1965; Chernoff and Hall, 1979; Parenti and Tigano, 1993; Tigano and Ferrito, 1984, 1985; Tigano et al., 1999, 2001; Doadrio et al., 2002; Ferrito et al., 2003, 2007; Garcia et al., 2009; Costa, 2010, 2011; Reichenbacher and Reichard, 2014; Reichenbacher et al., 2007). However, the examination of variation in extant populations can provide only a snapshot of morphological variation at the tips of the phylogeny. In order to assess the manner and rate at which variation has changed through time within a single lineage, palaeontological data are essential.

The aim of this study is to quantify intraspecific variation in meristic and morphometric characters, and to examine similarities in the distribution of this variation across multiple species in a clade. We compare the degree of variation in different regions of the axial skeleton (fins versus vertebral column). We hypothesize that fin characters are more variable than vertebral characters across all species, as high levels of variability in late-forming 
TABLE 1. Examples of previous studies on phenotypic variation in populations of fossil fishes.

\begin{tabular}{|c|c|c|c|c|c|c|}
\hline Species & Locality & Age & Environment & Objective & Characters & Source \\
\hline $\begin{array}{l}\text { Kenyaichthys } \\
\text { kipkechi }\end{array}$ & $\begin{array}{l}\text { Lukeino } \\
\text { Formation, } \\
\text { Tugen Hills, } \\
\text { (Kenya) }\end{array}$ & $\begin{array}{l}\text { late } \\
\text { Miocene }\end{array}$ & $\begin{array}{l}\text { Freshwater to } \\
\text { brackish } \\
\text { environment }\end{array}$ & $\begin{array}{l}\text { Description of } \\
\text { Kenyaichthy; } \\
\text { Phylogenetic } \\
\text { analyses }\end{array}$ & $\begin{array}{l}\text { Various } \\
\text { morphometric and } \\
\text { meristic characters }\end{array}$ & $\begin{array}{l}\text { Altner and } \\
\text { Reichenbacher } \\
(2015)\end{array}$ \\
\hline $\begin{array}{l}\text { Thaumaturus } \\
\text { intermedius, } \\
\text { Atractosteus } \\
\text { messelensis }\end{array}$ & $\begin{array}{l}\text { Messel } \\
\text { Formation } \\
\text { (Germany) }\end{array}$ & $\begin{array}{l}\text { middle } \\
\text { Eocene }\end{array}$ & Freshwater lake & $\begin{array}{l}\text { Phenotypic } \\
\text { variation }\end{array}$ & $\begin{array}{l}\text { Meristic counts of } \\
\text { vertebrae, rays and } \\
\text { supports of the } \\
\text { caudal fin; } \\
\text { Measurements of } \\
\text { various characters } \\
\text { from the skull, } \\
\text { intermuscular } \\
\text { bones, axial } \\
\text { skeleton and } \\
\text { ganoin patterns }\end{array}$ & $\begin{array}{l}\text { Micklich and } \\
\text { Klappert (2004) }\end{array}$ \\
\hline $\begin{array}{l}\text { Lepisosteus } \\
\text { bemisi, } \\
\text { Atractosteus } \\
\text { simplex, A. } \\
\text { messelensis, A. } \\
\text { atrox, Cuneatus } \\
\text { cuneatus, } \\
\text { Cuneatus wileyi }\end{array}$ & $\begin{array}{l}\text { Green River } \\
\text { Formation } \\
\text { (USA), } \\
\text { Messel } \\
\text { Formation } \\
\text { (Germany) }\end{array}$ & $\begin{array}{l}\text { early- } \\
\text { middle } \\
\text { Eocene }\end{array}$ & Freshwater lake & $\begin{array}{l}\text { Phenotypic } \\
\text { variation }\end{array}$ & $\begin{array}{l}\text { Various meristic } \\
\text { and ratio characters } \\
\text { from the skull, fins, } \\
\text { and postcranial } \\
\text { axial skeleton }\end{array}$ & Grande (2010) \\
\hline $\begin{array}{l}\text { Amyzon } \\
\text { aggregatum }\end{array}$ & $\begin{array}{l}\text { Horsefly } \\
\text { beds, } \\
\text { British } \\
\text { Columbia } \\
\text { (Canada) }\end{array}$ & $\begin{array}{l}\text { middle } \\
\text { Eocene }\end{array}$ & Freshwater lake & $\begin{array}{l}\text { Microstratigraphic } \\
\text { analyses of } \\
\text { phenotypic } \\
\text { variation }\end{array}$ & $\begin{array}{l}\text { Meristic counts of } \\
\text { vertebrae, fin rays } \\
\text { and anal } \\
\text { pterygiophores }\end{array}$ & $\begin{array}{l}\text { Barton and } \\
\text { Wilson (1999) }\end{array}$ \\
\hline $\begin{array}{l}\text { Scaumenacia } \\
\text { curta }\end{array}$ & $\begin{array}{l}\text { Escuminac } \\
\text { Formation } \\
\text { (Canada) }\end{array}$ & $\begin{array}{l}\text { Late } \\
\text { Devonian }\end{array}$ & $\begin{array}{l}\text { Estuarine } \\
\text { (brackish/ } \\
\text { fluctuating salinity) }\end{array}$ & $\begin{array}{l}\text { Phenotypic } \\
\text { variation }\end{array}$ & $\begin{array}{l}\text { Skull shape, dermal } \\
\text { bone configuration }\end{array}$ & Cloutier (1997) \\
\hline Semionotus & $\begin{array}{l}\text { Newark } \\
\text { Basin, } \\
\text { New Jersey } \\
\text { (USA) }\end{array}$ & $\begin{array}{l}\text { Late } \\
\text { Triassic - } \\
\text { Early } \\
\text { Jurassic }\end{array}$ & Freshwater lakes & $\begin{array}{l}\text { Estimation of } \\
\text { speciation rate }\end{array}$ & $\begin{array}{l}\text { Dorsal-ridge scales, } \\
\text { body shape }\end{array}$ & McCune (1996) \\
\hline Semionotus & $\begin{array}{l}\text { Towaco } \\
\text { Formation, } \\
\text { Newark } \\
\text { Basin, } \\
\text { New Jersey } \\
\text { (USA) }\end{array}$ & $\begin{array}{l}\text { Early } \\
\text { Jurassic }\end{array}$ & Freshwater lake & $\begin{array}{l}\text { Stratigraphical } \\
\text { distribution }\end{array}$ & Dorsal-ridge scales & McCune (1990) \\
\hline $\begin{array}{l}\text { Gasterosteus } \\
\text { doryssus }\end{array}$ & $\begin{array}{l}\text { Truckee } \\
\text { Formation, } \\
\text { Nevada } \\
\text { (USA) }\end{array}$ & Miocene & Saline lake & $\begin{array}{l}\text { Temporal } \\
\text { variation in } \\
\text { morphology }\end{array}$ & $\begin{array}{l}\text { Meristic counts of } \\
\text { dorsal spines, } \\
\text { predorsal } \\
\text { pterygiophores, } \\
\text { dorsal and anal fin } \\
\text { rays; } \\
\text { Measurements of } \\
\text { pelvic structures } \\
\text { and body length }\end{array}$ & $\begin{array}{l}\text { Bell and } \\
\text { Haglund (1982), } \\
\text { Bell et al. } \\
\text { (1985), } \\
\text { Bell and } \\
\text { Legendre } \\
\text { (1987) }\end{array}$ \\
\hline $\begin{array}{l}\text { Kerocottus } \\
\text { divaricatus } \\
\text { K. pontifex, } \\
\text { K. hypoceras, } \\
\text { Kerocottus sp., } \\
\text { Myoxocephalus } \\
\text { idahoensis }\end{array}$ & $\begin{array}{l}\text { Glenns Ferry } \\
\text { Formation, } \\
\text { Idaho (USA) }\end{array}$ & Pliocene & $\begin{array}{l}\text { Freshwater Rift } \\
\text { lake }\end{array}$ & $\begin{array}{l}\text { Intralacustrine } \\
\text { speciation }\end{array}$ & $\begin{array}{l}14 \text { characters of } \\
\text { preopercles }\end{array}$ & Smith (1987) \\
\hline
\end{tabular}




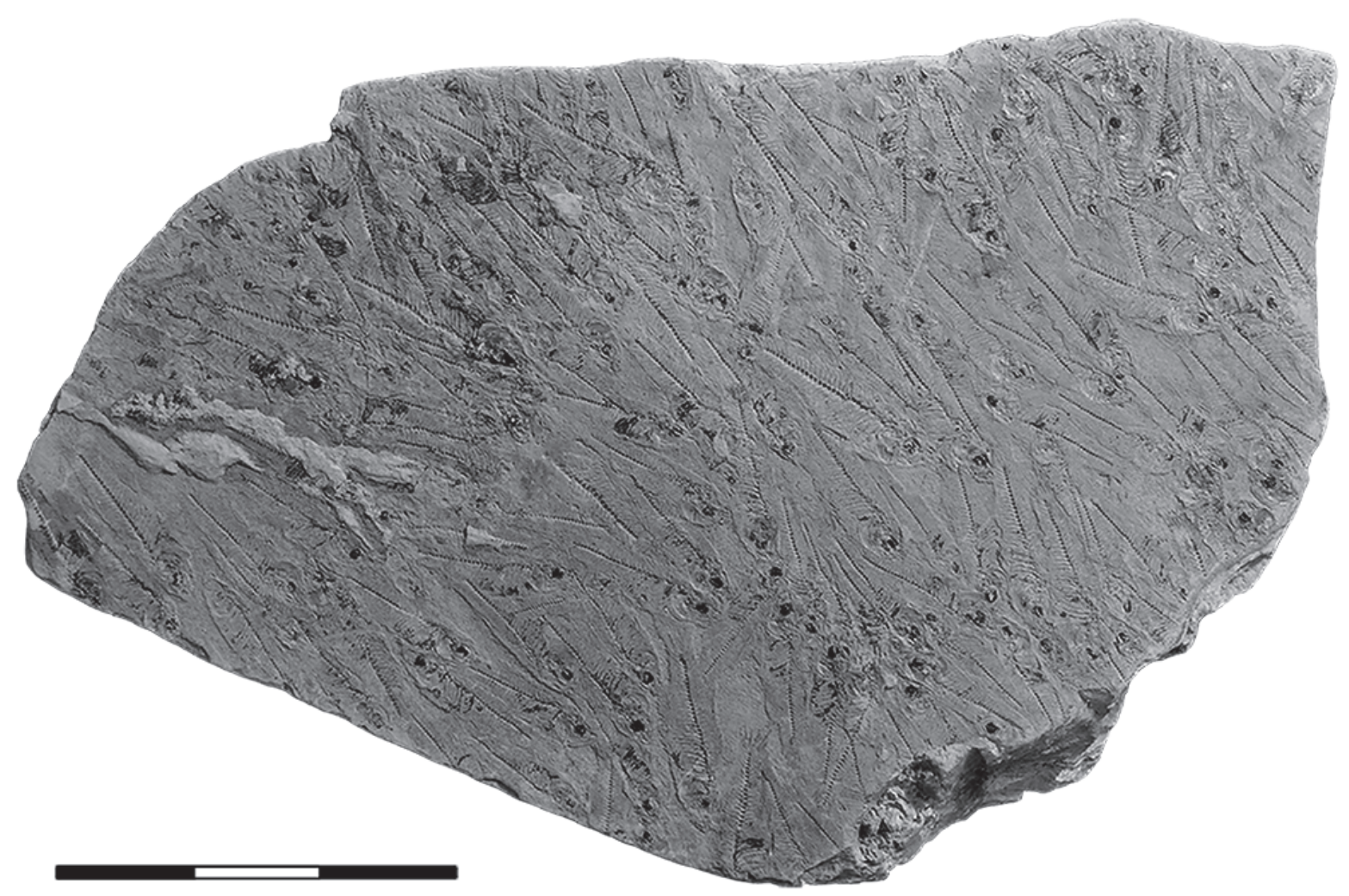

FIGURE 1. Photograph of a plate with Paralebias cephalotes (P.36131, NHM, collected from Aix-en-Provence, France). Scale bar equals $6 \mathrm{~cm}$.

and peripherally located serially repeated elements have been reported in both developmental and palaeontological studies (Cloutier et al., 2010; Barton and Wilson, 1999). In addition, we examine the relationship between meristic and morphometric variation. Although logically meristic variation should result in an equal degree of morphometric variation, the relationship between these is rarely explicitly assessed. The traits we examine are relatively easy to obtain and are commonly reported in the literature. These include vertebral count (Winkler et al., 2012; Maxwell and Wilson, 2013; Aguirre et al., 2014) and median fin length (Webb, 1984), which pertain directly to fish body shape and thus ecomorphology.

\section{MATERIALS AND METHODS}

In order to obtain an estimate of variability in phenotypic features, morphometric and meristic data (characters adopted from Barton and Wilson [1999] and Hubbs and Lagler [1964]) were collected for three species of fossil killifish: Prolebias rhenanus Gaudant, 1981, Pr. stenoura Sauvage, 1874, and Paralebias cephalotes (Agassiz, 1839)
(Figure 2; Appendix). Each of these species of killifishes occurs at high abundance in geographically restricted areas. We sampled the following meristic characters: total vertebrae (TV), precaudal vertebrae (PV), caudal vertebrae (CV), dorsal pterygiophores (DP), and anal pterygiophores (AP). To minimise error in meristic variables, we counted meristic variables twice for each specimen, once from the anterior and once from the posterior end of the column (following Barton and Wilson, 1999). We did not include counts of fin rays as they were often badly preserved and displaced. We also collected measurement data (in $\mathrm{mm}$ ), including standard length (SL; from the anterior part of the head to the end of the hypural plate), total length of vertebral column (TVL; from the first precaudal vertebra to the posterior end of the hypural plate), length of precaudal and caudal regions of the vertebral column (PCL and $\mathrm{CL}$; from the first to the most posterior precaudal vertebrae and from the most anterior caudal vertebra to the posterior end of the hypural plate, respectively), and length of dorsal and anal fin bases (DPL and APL) (Table 2, Figures 3,4$)$. To avoid damage to the fossils and to obtain more accurate measurements for small 

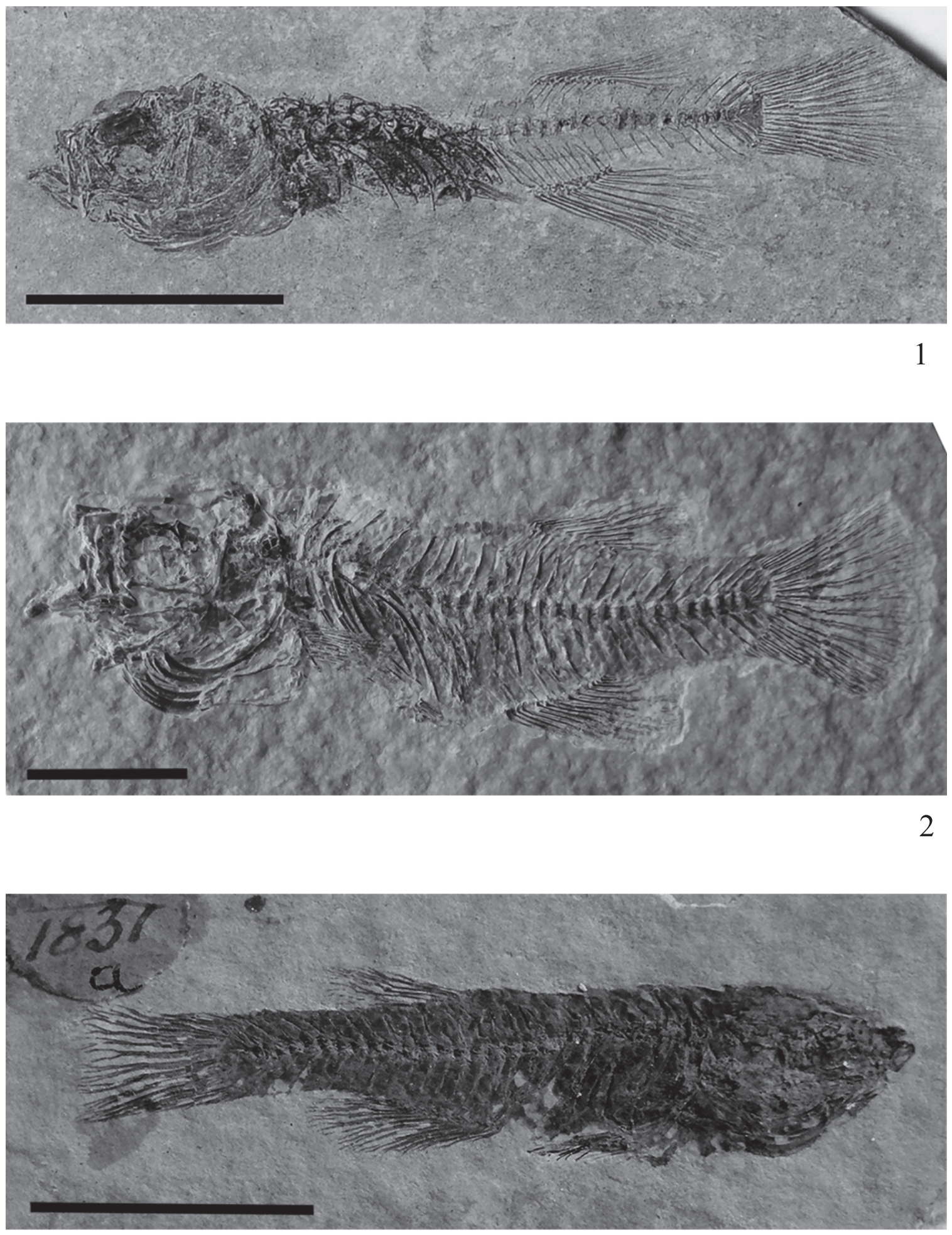

FIGURE 2. Photographs of fossil killifish species examined in this study. 1, Prolebias rhenanus (Ru 99, Naturhistorisches Museum Basel); 2, Pr. stenoura (28491 n, NHM); 3, Paralebias cephalotes (P.1831a, NHM). Scale bars equal $1 \mathrm{~cm}$. 
TABLE 2. Mean \pm standard deviation and range (in parentheses) of morphometric and meristic characters for specimens of Prolebias rhenanus, Pr. stenoura and Paralebias cephalotes.

\begin{tabular}{lccc}
\hline Character & $\begin{array}{c}\text { Prolebias rhenanus } \\
(\mathbf{n}=\mathbf{6 7})\end{array}$ & $\begin{array}{c}\text { Prolebias stenoura } \\
(\mathbf{n}=\mathbf{4 0})\end{array}$ & $\begin{array}{c}\text { Paralebias cephalotes } \\
(\mathbf{n}=\mathbf{1 4 1})\end{array}$ \\
\hline Measurements (mm): & & & $25.1 \pm 3.0$ \\
Standard length & $23.4 \pm 3.8$ & $35.9 \pm 7.9$ & $(19-38.8)$ \\
& $(13.9-33.5)$ & $(19.0-51.0)$ & $6.9 \pm 1.1$ \\
Precaudal vertebral column length & $7.6 \pm 1.6$ & $11.0 \pm 3.1$ & $(4.9-12)$ \\
Caudal vertebral column length & $(4.0-12)$ & $(5.0-15.9)$ & $11.4 \pm 1.3$ \\
& $9.7 \pm 1.3$ & $15.2 \pm 3.2$ & $(8.1-15.5)$ \\
Dorsal fin base length & $(5.6-12.3)$ & $(8.3-20.2)$ & $(1.4-4.2)$ \\
& $3.0 \pm 0.3$ & $(2.3-6.9)$ & $3.4 \pm 0.6$ \\
Anal fin base length & $(2.2-3.6)$ & $4.6 \pm 1.3$ & $(2.1-5.6)$ \\
& $3.3 \pm 0.4$ & $(2.3-8.5)$ & \\
Meristic: & $(2.6-4.1)$ & & $29.5 \pm 1.0$ \\
Total vertebrae number & & & $(27-32)$ \\
Precaudal vertebrae number & & $30.0 \pm 0.7$ & $(10.4 \pm 0.6$ \\
Caudal vertebrae number & $28.5 \pm 0.7$ & $(29-31)$ & $12)$ \\
Dorsal pterygiophore number & $(27-30)$ & $(11-13)$ & $(19.2 \pm 0.9$ \\
Anal pterygiophore number & $11.9 \pm 0.3$ & $18.1 \pm 0.7$ & $8.6 \pm 1.2$ \\
\end{tabular}

specimens, we took photos of all specimens and from them obtained measurements using the software Photoshop CS6 (Adobe Systems Incorporated, San Jose, CA, USA). We used the line tool to precisely align curves and lines to the different length parameters and later, we could easily measure the length of these shapes at the scale in the photographs. Due to incompleteness or disarticulation, not all data could be collected for every specimen.

Sixty-seven specimens of Prolebias rhenanus from the Lower Oligocene of the locality "Rüssgraben bei Kleinkems" (Baden-Württemberg, Germany) were included in the study (Figure 2.1). These were originally from the collection of Mathieu Mieg and are housed in the Naturhistorisches Museum of Basel, Switzerland. Mieg (1892) reported the occurrence of those fossil fishes within two thin layers consisting of "Plattiger Steinmergel" at a section at Rüssgraben bei Kleinkems. These layers are thin, not exceeding $0.15 \mathrm{~m}$ in thickness, and are separated by approximately $1 \mathrm{~m}$ of sediment (Mieg, 1892). Prolebias rhenanus has been hypothesized to tolerate fresh to brackish water conditions (Gaudant, 1981a) and inhabited a shallow saline lake periodically filled by freshwater from precipitation (Lutz, 1997).
We also sampled 40 specimens of Prolebias stenoura from the Lower Oligocene of Puy-deDôme, France, housed in the Natural History Museum of London (NHM) since the nineteenth century (Gaudant, 2012; Figure 2.2). The precise stratigraphic position of these specimens is unknown, but the specimens of the Croizet Collection, to which many of the specimens are attributed, were found in different lacustrine sediments around Corent (Giraud, 1902; Pécoil, 1938; Gorin, 1975). Prolebias stenoura occurred in a shallow meromictic lake with fresh to slightly brackish water conditions at the surface (Gaudant, 2012).

Lastly, we sampled 141 specimens of Paralebias cephalotes from the Upper Oligocene of Aixen-Provence (Bouche-du-Rhône, France), housed in the Natural History Museum of London (Figure 2.3). Paralebias cephalotes was recovered from 12 different horizons during a modern excavation at Aix-en-Provence (Gaudant, 1978). The abundance of the species and the associated fauna fluctuated throughout the $1.6 \mathrm{~m}$ section. Variable species abundance and faunal composition are hypothesized to reflect changes in salinity in the lake, and $P a$. cephalotes appears to have inhabited freshwa- 


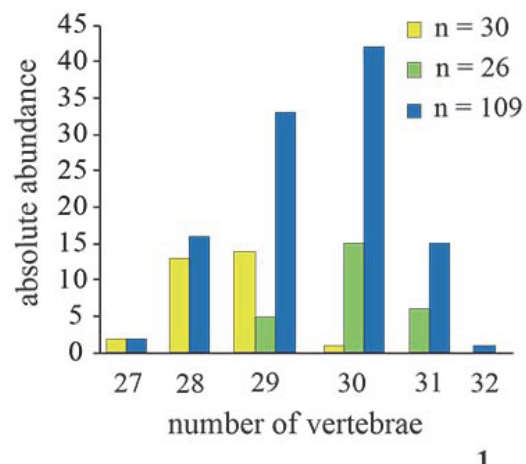

1

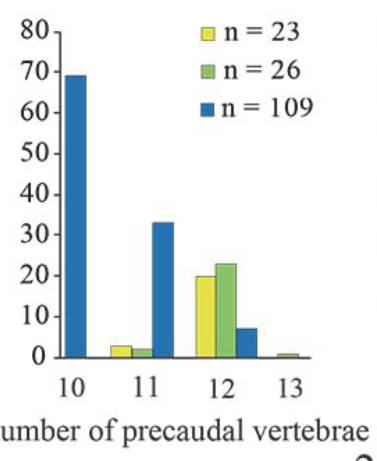

2

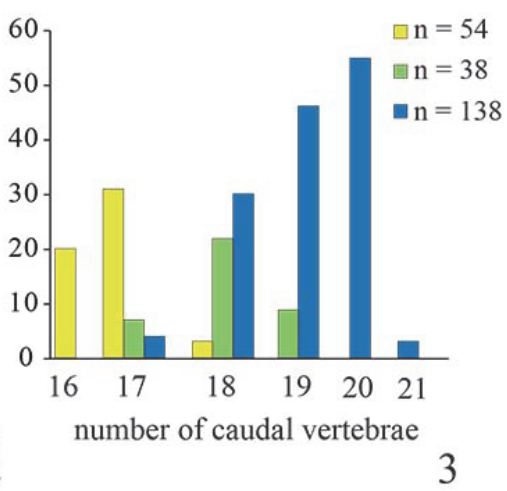

3
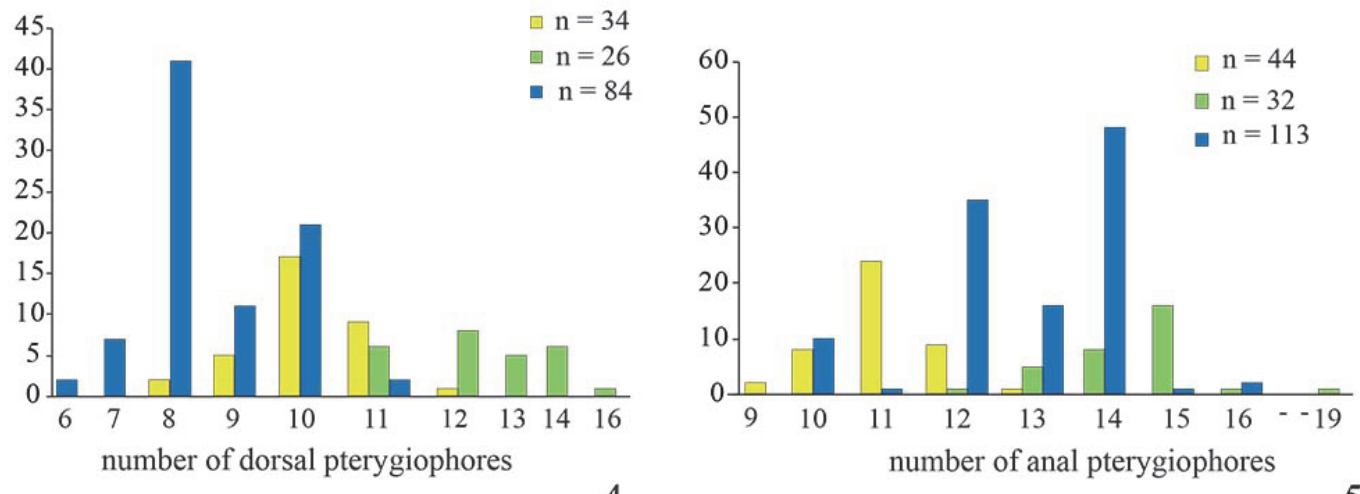

4

FIGURE 3. Bar charts showing frequency distribution of meristic characters for the three fossil Killifish species Prolebias rhenanus (yellow), Pr. stenoura (green) and Paralebias cephalotes (blue). 1, number of vertebrae; 2, number of precaudal vertebrae; 3 , number of caudal vertebrae; 4 , number of dorsal pterygiophores; 5 , number of anal pterygiophores.

ter to slightly brackish environments (Gaudant, 1978).

\section{Statistical analyses}

Morphological measurements were log-transformed to equalize variance between different measurements, and all measurement data were corrected for size using multiple regression with the skull length as the independent variable. Size correction is necessary to exclude predictable ontogenetic changes in morphometric traits (McCoy et al., 2006). We selected multiple regression on skull length to standardize the data versus simply standardizing measurements as fractions of total or standard length because body length is not independent of length of the vertebral column, the trait of interest. As meristic traits are fixed during early ontogeny, they are independent of body size and so size-correction was not performed. To obtain an estimate of trait variability, we calculated the coefficients of variation (COV: standard devia- tion divided by the trait mean) for each character using log-transformed and size-corrected data. We tested for overall differences in variation between fin characters and vertebral characters, and between morphometric characters and meristic characters using a Mann-Whitney U-test. Pairwise correlations between morphometric and meristic and fin and vertebral characters were examined using Spearman's rho. All analyses were performed using the statistical program PAST (Hammer et al., 2001).

\section{RESULTS}

\section{Observed variation of characters}

We obtained similar vertebral counts to those presented in Gaudant (2012) in Prolebias stenoura, but the range of dorsal and anal fin pterygiophore counts was much greater in our work (Table 2). In all the counts of Problebias rhenanus and Paralebias cephalotes, we found broader ranges 


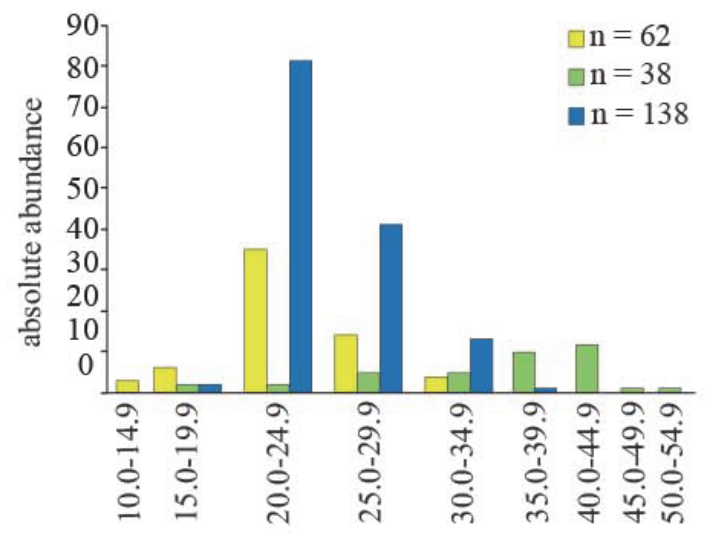

Standard length (mm)

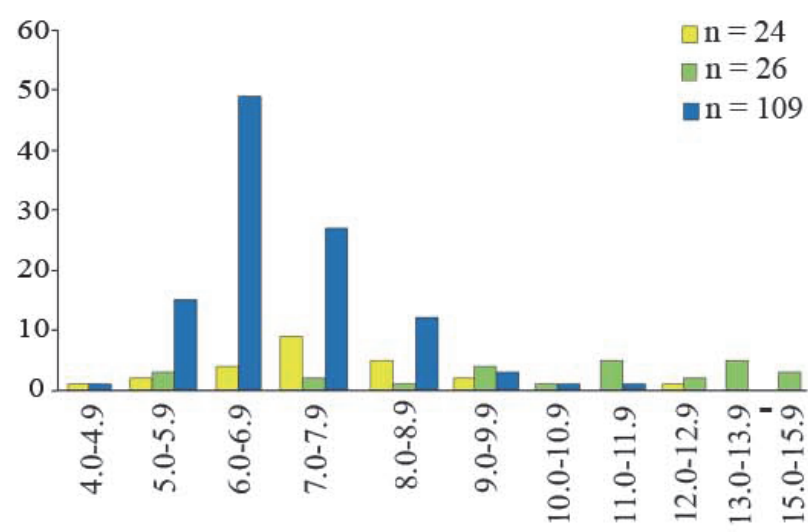

Precaudal length of vertebral column (mm)

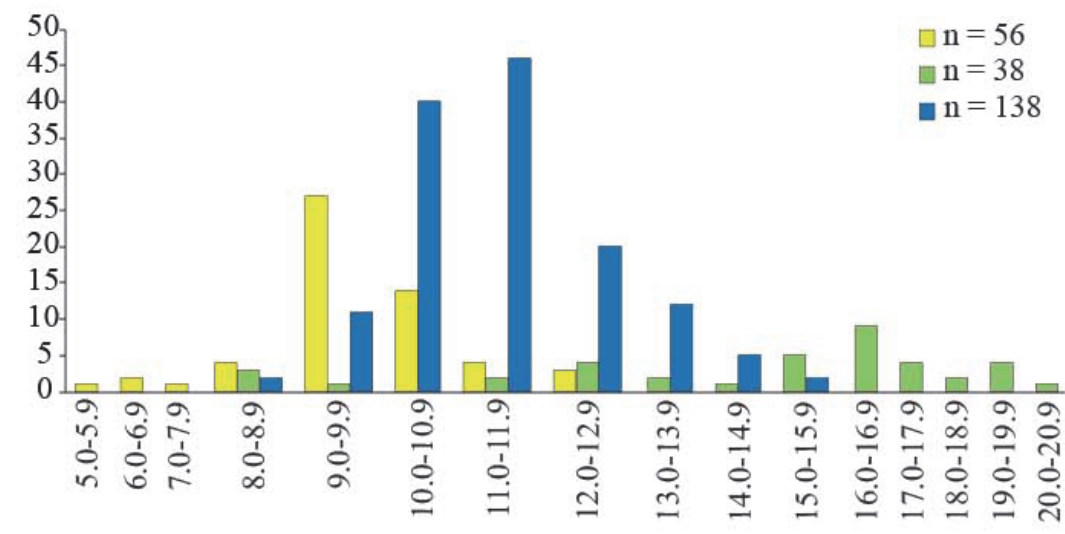

caudal length of vertebral column (mm)

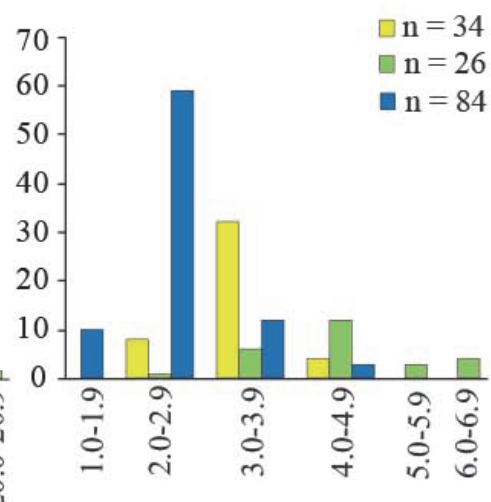

length of dorsal fin base (mm)

3

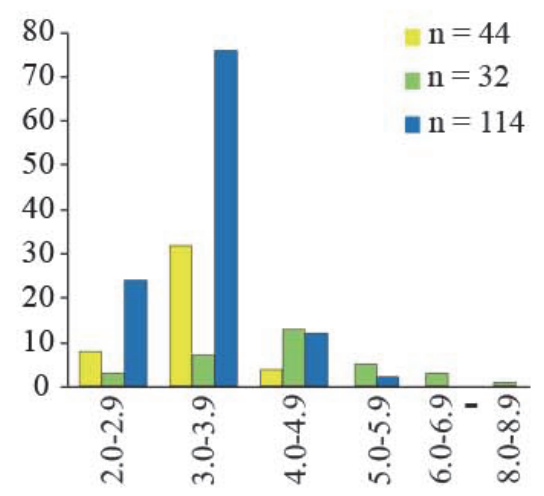

length of anal fin base (mm)

5

FIGURE 4. Bar charts showing frequency distribution of morphometric data (in $\mathrm{mm}$ ) for the three fossil Killifish species Prolebias rhenanus (yellow), Pr. stenoura (green) and Paralebias cephalotes (blue). 1, standard length; 2, precaudal length of vertebral column; 3 , caudal length of vertebral column; 4 , length of dorsal fin base; 5 , length of anal fin base. 
TABLE 3. Coefficient of variation (COV) for morphometric and meristic characters.

\begin{tabular}{lccc}
\hline \multicolumn{1}{c}{ Character } & $\begin{array}{c}\text { Prolebias } \text { rhenanus } \\
(\mathbf{n}=\mathbf{6 7})\end{array}$ & $\begin{array}{c}\text { Coefficient of Variation } \\
\text { Prolebias stenoura } \\
(\mathbf{n}=\mathbf{4 0})\end{array}$ & $\begin{array}{c}\text { Paralebias cephalotes } \\
(\mathbf{n}=\mathbf{1 4 1})\end{array}$ \\
\hline Measurements $(\mathbf{m m}):$ & & & 3.5 \\
Standard length & 5.5 & 6.9 & 3.9 \\
Total vertebral column length & 5.2 & 8.5 & 7.7 \\
Precaudal vertebral column length & 10.8 & 13.5 & 4.6 \\
Caudal vertebral column length & 6.4 & 9.0 & 24.0 \\
Dorsal fin base length & 10.8 & 16.8 & 13.8 \\
Anal fin base length & 9.8 & 18.4 & \\
& & & 3.4 \\
Meristic: & & & 5.9 \\
Total vertebrae number & 2.4 & 2.2 & 4.7 \\
Precaudal vertebrae number & 2.9 & 2.9 & 13.5 \\
Caudal vertebrae number & 3.5 & 3.6 & 10.3 \\
Dorsal pterygiophore number & 8.8 & 10.3 & \\
Anal pterygiophore number & 7.5 & 8.4 & \\
\hline
\end{tabular}

than in previous studies (Gaudant, 1981a, b, 2009). The differences in ranges are possibly attributable to different sample size.

In Prolebias rhenanus, lengths of the precaudal vertebral column and of the fin bases show the most variation $\left(\mathrm{COV}_{\mathrm{PCL}}=10.8, \mathrm{COV}_{\mathrm{DPL}}=10.8\right.$, $\mathrm{COV}_{\mathrm{APL}}=9.8$; Table 3). This is followed by variation in pterygiophore counts and axial length variables $\left(\mathrm{COV}_{\mathrm{DP}}=8.8, \mathrm{COV}_{\mathrm{AP}}=7.5, \mathrm{COV}_{\mathrm{CL}}=6.4, \mathrm{COV}_{\mathrm{SL}}=\right.$ $5.5, \mathrm{COV}_{\mathrm{TVL}}=5.2$ ). Vertebral counts were the least variable characters in the sample; the number of caudal vertebrae was more variable than the number of precaudal vertebrae $\left(\mathrm{COV}_{\mathrm{TV}}=2.4, \mathrm{COV}_{\mathrm{PCV}}\right.$ $\left.=2.9, \mathrm{COV}_{\mathrm{CV}}=3.5\right)$. Coefficients of variation between fin and vertebral characters are not significantly different (mean ranks 3.1 and $2.5, P=$ 0.07 ), nor were coefficients of variation between count and length variables (mean ranks 1.9 and 4.1, $P=0.12$ ).

Based on the data presented here, length of the dorsal and anal fin bases was most variable $\left(\mathrm{COV}_{\mathrm{APL}}=18.4, \mathrm{COV}_{\mathrm{DPL}}=16.8 ; \mathrm{COV}_{\mathrm{PCL}}=13.5\right.$, see Table 3) followed by pterygiophore counts and axial length measurements $\left(\mathrm{COV}_{\mathrm{DP}}=10.3, \mathrm{COV}_{\mathrm{AP}}\right.$ $\left.=8.8, \mathrm{COV}_{\mathrm{SL}}=6.9, \mathrm{COV}_{\mathrm{TVL}}=8.5, \mathrm{COV}_{\mathrm{CL}}=9.0\right)$ in Prolebias stenoura. Vertebral count variables showed the low coefficients of variation and with caudal counts being the most variable $\left(\mathrm{COV}_{\mathrm{TV}}=\right.$ 2.2, $\left.\mathrm{COV}_{\mathrm{PCV}}=2.9, \mathrm{COV}_{\mathrm{CV}}=3.6\right)$. Morphometric characters were not significantly more variable than meristic characters (mean ranks 4.3 and 1.7, $P=0.06$ ), and differences in variation between fin and vertebral characters were not significant (mean ranks 3.0 and 2.5, $P=0.11$ ).

In Paralebias cephalotes, lengths of the fin bases are the most variable traits, followed by pterygiophore counts $\left(\mathrm{COV}_{\mathrm{DPL}}=24.0, \mathrm{COV}_{\mathrm{APL}}=13.8\right.$, $\mathrm{COV}_{\mathrm{DP}}=13.5$ and $\left.\mathrm{COV}_{\mathrm{AP}}=10.3\right)$. Measurements and counts of the precaudal vertebral column are the most variable vertebral measures $\left(\mathrm{COV}_{\mathrm{PCL}}=\right.$ 7.7 and $\mathrm{COV}_{\mathrm{PCV}}=5.9$ ), followed by total and caudal vertebral characters $\left(\mathrm{COV}_{\mathrm{SL}}=3.5, \mathrm{COV}_{\mathrm{TVL}}=\right.$ 3.9, $\mathrm{COV}_{\mathrm{CL}}=4.6, \mathrm{COV}_{\mathrm{TV}}=3.4$ and $\left.\mathrm{COV}_{\mathrm{CV}}=4.7\right)$. Coefficients of variation of fin characters are higher than those of vertebral characters (mean ranks 3.4 and 2.1, $P=0.009$ ). Mean ranks of morphometric and meristic characters do not differ significantly from each other (mean ranks 3.7 and 2.6, $P=$ 0.90).

\section{Correlation of characters}

Only significant correlations are reported in the text; see Tables 4-6 for all morphometric vs. meristic and fin vs. vertebral correlations.

In Prolebias rhenanus the number of precaudal vertebrae is negatively correlated with anal pterygiophore count (correlation coefficient: $S=-0.54$, $P=0.02$ ). Precaudal length and caudal length of 
TABLE 4. Correlation matrix (correlation coefficient below the diagonal; p-values above the diagonal) for fin vs. vertebral and meristic vs. morphometric characters of Prolebias rhenanus. Significant correlations $(\alpha=0.05)$ are highlighted in bold face fonts. Abbreviations for morphometric characters: SL, standard length; TVL, total length of vertebral column; PCL and CL, length of precaudal and caudal region of vertebral column; DPL and APL, length of dorsal and anal fin bases. Abbreviations for meristic characters: TV, total number of vertebrae; PV and CV, number of precaudal and caudal vertebrae; DP and AP, number of dorsal and anal pterygiophores.

\begin{tabular}{lccccccccccc}
\hline & SL & DPL & APL & TVL & PCL & CL & DP & AP & TV & PCV & CV \\
\hline SL & & & & & & & 0.949 & 0.195 & 0.120 & 0.478 & 0.477 \\
DPL & & & & $\mathbf{0 . 0 0 0 1}$ & $\mathbf{0 . 0 0 4 3}$ & $\mathbf{0 . 0 3 5 8}$ & $\mathbf{0 . 0 0 0 3}$ & 0.783 & 0.407 & 0.596 & 0.343 \\
APL & & & & $\mathbf{7 . 5 3 \times 1 0 - 5}$ & $\mathbf{0 . 0 1 6 9}$ & $\mathbf{9 . 1 8 \times 1 0 - 7}$ & 0.920 & 0.641 & 0.886 & 0.724 & 0.986 \\
TVL & & 0.466 & 0.481 & & & & 0.949 & 0.190 & 0.0914 & 0.424 & 0.589 \\
PCL & & 0.358 & 0.303 & & & & 0.604 & 0.172 & 0.130 & 0.424 & 0.391 \\
CL & & 0.267 & 0.577 & & & & 0.579 & 0.480 & 0.325 & 0.374 & 0.22 \\
DP & -0.0115 & 0.579 & -0.0179 & -0.0115 & -0.0923 & -0.0986 & & & 0.052 & 0.9324 & 0.234 \\
AP & 0.199 & -0.0428 & 0.0724 & 0.201 & 0.210 & -0.109 & & & 0.358 & $\mathbf{0 . 0 2 3 8}$ & 0.0682 \\
TV & -0.290 & 0.157 & -0.0273 & -0.314 & -0.283 & -0.186 & 0.453 & -0.211 & & & \\
PCV & -0.156 & 0.117 & -0.0779 & -0.175 & -0.175 & 0.195 & 0.024 & -0.545 & & & \\
CV & -0.0988 & 0.132 & -0.0024 & -0.0751 & -0.119 & -0.170 & 0.228 & -0.295 & & & \\
\hline
\end{tabular}

TABLE 5. Correlation matrix (correlation coefficient below the diagonal; $p$-values above the diagonal) for fin vs. vertebral and meristic vs. morphometric characters of Prolebias stenoura. Significant correlations $(\alpha=0.05)$ are highlighted in bold face fonts. Abbreviations are the same as in Table 4.

\begin{tabular}{lccccccccccc}
\hline & SL & DPL & APL & TVL & PCL & CL & DP & AP & TV & PCV & CV \\
\hline SL & & & & & & & 0.629 & 0.907 & 0.580 & 0.219 & 0.774 \\
DPL & & & & 0.553 & 0.899 & 0.628 & 0.103 & 0.366 & 0.185 & 0.621 & 0.252 \\
APL & & & & 0.112 & 0.451 & $\mathbf{0 . 0 4 4 4}$ & 0.879 & $\mathbf{0 . 0 1 3 8}$ & 0.299 & 0.0758 & 0.0868 \\
TVL & & 0.099 & 0.262 & & & & 0.629 & 0.907 & 0.580 & 0.219 & 0.774 \\
PCL & & 0.0212 & 0.126 & & & & 0.292 & 0.584 & 0.770 & 0.396 & 0.737 \\
CL & & 0.0811 & 0.328 & & & & 0.862 & 0.558 & 0.915 & 0.220 & 0.681 \\
DP & -0.0994 & 0.327 & 0.0313 & -0.0994 & -0.215 & -0.0342 & & & 0.746 & 0.251 & 0.667 \\
AP & 0.0214 & -0.166 & 0.431 & 0.0214 & -0.101 & 0.108 & & & 0.344 & 0.106 & 0.0762 \\
TV & -0.114 & -0.268 & 0.212 & -0.114 & -0.0604 & 0.0219 & -0.0849 & 0.212 & & & \\
PCV & -0.250 & -0.102 & -0.354 & -0.250 & -0.174 & -0.249 & 0.292 & -0.354 & & & \\
CV & 0.0482 & -0.190 & 0.282 & 0.0482 & 0.0563 & 0.0689 & -0.0885 & 0.318 & & & \\
\hline
\end{tabular}

the vertebral column are both positively correlated with length of the fin bases (PCL: $S=0.36, P=$ $0.004 ; S=0.3, P=0.01 ; \mathrm{CL}: S=0.27, P=0.03 ; S$ $\left.=0.58, P=9.18 \times 10^{-7}\right)$. The relationship between length of the dorsal fin base and number of dorsal pterygiophores is significant and positive $(S=0.58$, $P=0.0003$ ) (Table 4).

In Prolebias stenoura, caudal length of the vertebral column is positively correlated with length of the anal fin base $(S=0.32 ; P=0.04)$. The relationship between the base of the anal fin and the number of anal pterygiophores is significant and positive $(S=0.43, P=0.01$ ) (Table 5).

In Paralebias cephalotes, fin base lengths are positively correlated with all vertebral length traits. Caudal length is negatively correlated with the number of precaudal vertebrae $(S=-0.49, P=$ 0.04 ), but positively correlated with number of caudal vertebrae $(S=0.25, P=0.002)$. The length of the dorsal fin base is significantly correlated with the number of dorsal pterygiophores $(S=0.46, p$ values $=9.44 \times 10^{-6}$ ), and the length of the anal fin base is significantly correlated with the number of 
TABLE 6. Correlation matrix (correlation coefficient below the diagonal; $p$-values above the diagonal) for fin vs. vertebral and meristic vs. morphometric characters of Paralebias cephalotes. Significant correlations $(\alpha=0.05)$ are highlighted in bold face fonts. Abbreviations are the same as in Table 4.

\begin{tabular}{lccccccccccc}
\hline & SL & DPL & APL & TVL & PCL & CL & DP & AP & PCV & CV & TV \\
\hline SL & & & & & & & 0.458 & 0.352 & 0.355 & 0.323 & 0.749 \\
DPL & & & & $\mathbf{0 . 0 0 0 1}$ & $\mathbf{0 . 0 1 6 5}$ & $\mathbf{1 . 0 4 \times 1 0 - 5}$ & $\mathbf{9 . 4 4 \times 1 0 - 6}$ & 0.557 & 0.603 & 0.322 & 0.582 \\
APL & & & & $\mathbf{8 . 9 2 \times 1 0 - 8}$ & $\mathbf{0 . 0 0 0 3}$ & $\mathbf{6 . 9 2 \times 1 0 - 9}$ & 0.185 & $\mathbf{7 . 0 2 \times 1 0 - 4}$ & 0.295 & 0.377 & 0.909 \\
TVL & & 0.322 & 0.436 & & & & 0.394 & 0.339 & 0.556 & 0.192 & 0.430 \\
PCL & & 0.204 & 0.302 & & & & 0.915 & 0.395 & 0.204 & 0.344 & 0.934 \\
CL & & 0.366 & 0.468 & & & & 0.152 & 0.418 & $\mathbf{0 . 0 4 4 4}$ & $\mathbf{0 . 0 0 2 3}$ & 0.145 \\
DP & 0.0820 & 0.463 & 0.146 & 0.0943 & 0.0118 & 0.158 & & & 0.735 & 0.651 & 0.986 \\
AP & -0.0884 & 0.0558 & 0.314 & -0.0907 & -0.0807 & -0.0770 & & & 0.474 & 0.849 & 0.584 \\
PCV & -0.0895 & -0.0503 & -0.101 & -0.0570 & 0.123 & -0.193 & -0.0421 & -0.0765 & & & \\
CV & 0.0847 & 0.0850 & 0.0759 & 0.112 & -0.0812 & 0.258 & 0.0501 & 0.0181 & & & \\
TV & 0.0310 & 0.0533 & 0.0111 & 0.0763 & -0.008 & 0.141 & -0.0022 & -0.0584 & & & \\
\hline
\end{tabular}

anal pterygiophores $\left(S=0.31, P=7.02 \times 10^{-4}\right)$ (Table 6).

\section{DISCUSSION}

Nearly identical patterns of intraspecific variation exist between the two species of Prolebias. Length of the fin base and of precaudal parts of the vertebral column are the most variable traits in both species, followed by pterygiophore counts, then other axial length measurements and, least variable, vertebral counts. The magnitude of the observed variation for most traits, including measurements and pterygiophores counts, is greater in Pr. stenoura, but the coefficient of variation for the vertebral counts are identical in both species. In neither species was there a significant difference in observed variation between fin and vertebral or meristic and morphometric traits. In the samples of both species, there is a positive relationship between caudal length of the vertebral column and length of the anal fin base. Interestingly, although $\operatorname{Pr}$. stenoura shows relatively greater amounts of variation for most traits, this variation appears to be stochastically distributed: for the trait combinations tested, Pr. rhenanus exhibits more and stronger covarying trait relationships.

The pattern of variation observed in Paralebias cephalotes is similar to Prolebias, with one major exception: precaudal length $\left(\mathrm{COV}_{\mathrm{PCL}}=7.7\right)$ is less variable in Paralebias while precaudal vertebral count $\left(\mathrm{COV}_{\mathrm{PCL}}=5.9\right)$ is more variable. However, as it was the case in Prolebias, this variation appears to be randomly distributed: precaudal length and the number of precaudal vertebrae are not significantly correlated, suggesting that the decrease in variation observed in the first and the increase in variation observed in the second are not due to trait integration. In addition, a significant difference in variability was detected between fin and vertebral characters, with vertebral characters being less variable in $\mathrm{Pa}$. cephalotes. The relative amount of variation observed was slightly, but not dramatically greater in $P$ a. cephalotes (mean ranks 3.7 and 2.6, $P=0.90$ ) than in Pr. stenoura (mean ranks 3.0 and $2.5, P=0.11$ ), and may be attributed to larger sample sizes in the former.

Decreased variation in precaudal length of the vertebral column and increased variation in precaudal count in Paralebias cephalotes in the absence of any correlation between the two traits suggests an underlying cause: variability in elongation of precaudal vertebrae. This pattern clearly does not extend into the caudal region, where a significant relationship exists between caudal length and number of caudal vertebrae, as reported in an extensive and phylogenetically broad examination of bony fishes species (Lindsey, 1975). Elongate fishes extend the vertebral column either through elongation of the vertebral centra or through addition of vertebrae (Ward and Mehta, 2010), and our results imply that variation in both vertebral number and vertebral length may be present in populations.

In Prolebias spp. caudal vertebral counts $\left(\mathrm{COV}_{\mathrm{CV}}=3.5\right.$ for Pr. rhenanus and 3.6 for Pr. stenoura, respectively) are significantly more variable than precaudal counts $\left(\mathrm{COV}_{\mathrm{PCV}}=2.9\right.$ for both species). The pre-ural caudal region of the vertebral 
column in fishes is hypothesized to be more variable than the precaudal region, as segmentation proceeds from anterior to posterior (Itazawa, 1963; Nagiec, 1977; Lindsey, 1988; Grande and Bemis, 1998; Barton and Wilson, 1999; Aguirre et al., 2014), and most actinopterygians add vertebrae to the caudal region preferentially (Ward and Mehta, 2014), suggesting increased variability in this region. However, this is not a universal rule: some actinopterygians do add vertebrae preferentially to the abdominal region (Mehta et al., 2010; Maxwell and Wilson, 2013), and this may result in increased variability in abdominal counts within species. Sexual dimorphism may also increase observed variation in abdominal vertebral counts preferentially relative to caudal counts due to selection for increased abdominal volume in females (Lindsey, 1975).

Intraspecific variation in vertebral counts is correlated with a multitude of factors in teleosts, including life history (McDowall, 2003), sex (Aguirre et al., 2014; Lindsey, 1975), habitat (Shikano and Merilä, 2011), and temperature/latitude/altitude (Barriga et al., 2013; Baumann et al., 2012; Hice et al., 2012; McDowall, 2003; Yamahira et al., 2006; Yamahira and Nishida, 2009). Heritability of vertebral numbers is high, but phenotypic plasticity is well documented (Lindsey, 1988; Yamahira and Nishida, 2009). Differences in sample size, multiyear sampling effects, salinity, and other habitat characteristics may influence the absolute amount of variation observed, as has been reported in other teleosts (e.g., McDowall, 2003; Shikano and Merilä, 2011), including killifishes (Maltagliati et al., 2003). Prolebias rhenanus and Paralebias cephalotes inhabited brackish waters with fluctuating salinity content, whereas Pr. stenoura inhabited freshwater lakes. As the pattern of variation between Problebias spp., which lived in different water conditions, is similar, differences in salinity do not seem to have affected such variation. Moreover, the number of precaudal vertebrae in fossil killifishes was difficult to observe, since the most anterior vertebrae are often badly preserved or covered by the skull (Gaudant, 1981a), and thus measurement error cannot be eliminated as a source of increased variation.

Variability between fin and vertebral characters is similar in Prolebias spp. (Prolebias rhenanus: mean ranks 3.0 and $2.5, P=0.11 ; \mathrm{Pr}$. stenoura: mean ranks 3.0 and $2.5, P=0.11$ ), but Paralebias cephalotes (mean ranks 3.7 and 2.6, $P$ $=0.90$ ) shows greater variability in characters pertaining to the median fins. However, even in Pro- lebias spp. traits pertaining to the dorsal and anal fins are extremely variable (Prolebias rhenanus: $\mathrm{COV}_{\mathrm{APL}, \mathrm{AP}, \mathrm{DPL}, \mathrm{DP}}=9.8,7.5,10.8,8.8$; Pr. stenoura: $\left.\mathrm{COV}_{\mathrm{APL}, \mathrm{AP}, \mathrm{DPL}, \mathrm{DP}}=18.4,8.4,16.8,10.3\right)$. Although descriptive statistics pertaining to morphological variation (i.e., mean, standard deviation) are rarely presented for extant cyprinodontiforms, those few data that are available are consistent with our observations. For instance, the $\mathrm{COV}_{\mathrm{TV}}$ and the COV of axial length measurements are less than those of both dorsal and anal fin ray counts in males of the extant poeciliid Gambusia quadruncus (Langerhans et al., 2012); females appear to be more variable than males but all COV values fall into the range reported in our fossil samples (e.g., $\left.\mathrm{COV}_{\left(\mathrm{TV}_{\text {P })}\right.}=2.4 \%\right)$. In three goodeid species belonging to Xenoophorus, length measurements pertaining to vertebral regions also had on average lower coefficients of variation than the lengths of the fin bases, with the length of the anal fin base showing the highest COV and the length of the axial skeleton anterior to the dorsal fin showing the least variation in all species. Count data were not available. As in Gambusia, females showed overall slightly higher amounts of variation than males (Fitzsimons, 1979).

Variation in vertebral counts should theoretically be lower than in pterygiophore (proximal radial) counts in fishes, based on a more terminal position of the latter in the developmental sequence (both in terms of patterning and ossification) resulting in an increased number of ways in which variation may be introduced (Lindsey, 1988). This effect may be amplified in fossil fishes, since pterygiophores ossify relatively late in ontogeny (e.g., Bird and Mabee, 2003; Grünbaum et al., 2012) and thus may not be preserved in smaller specimens even when present. Higher variability in pterygiophore counts than vertebral counts is supported in a species of catastomid (Barton and Wilson, 1999). Studies on variation in fishes have reported that fin traits are more variable than vertebral ones in general (Cloutier et al., 2010; Barton and Wilson, 1999; MacGregor and MacCrimmon, 1977). Median fins rely on the same positioning cues as the vertebral column early in development (Freitas et al., 2006) and later in development articulate with the neural and haemal spines (Figure 2) (Bird and Mabee, 2003). This suggests that, to a certain degree, the two sets of traits should be correlated: as the vertebrae grow longer, the bases of the fins are also constrained to become longer, and indeed this is what is observed in our studied samples, with all species showing a positive correlation 
between the lengths of at least one of the fin bases and the vertebral column. However, the lengths of the fin bases are also related to the number of pterygiophores, and this appears to be the underlying cause of observed variation in fin characters. Pterygiophores ossify late in development (FischerRousseau et al., 2009; Cloutier et al., 2010; Grünbaum et al., 2012), and environmentally induced plasticity is observed in their timing of ossification (Cloutier et al., 2010; Grünbaum et al., 2012) so it is uncertain whether variable ossification rather than meristic variability is promoting variation in fin characters.

In conclusion, our data suggest similarities in patterns of variation among closely related species, with possible divergence of trait variability between 'families' (Poeciliidae - Paralebias vs. Valenciidae - Prolebias: Costa, 2012; Gaudant, 2013). More thorough sampling within Cyprinodontiformes is needed to evaluate the time-scales over which such shifts occur. Divergence in patterns of trait covariance have previously been reported over a range of time and spatial scales (population: Game and Caley, 2006; stratigraphic: Maxwell and Dececchi, 2013; phylogenetic: Goswami et al., 2014), and variability in the amount of morphological variation present has been shown in a general way between populations (Game and Caley, 2006). Our results suggest that not only can the variancecovariance matrix be restructured, and different amounts of absolute variation be present (Wilson, 2013), but the variability of specific traits also changes over evolutionary time. The $\sim 10 \%$ absolute variation in vertebral numbers among individuals we found may have influenced locomotory performance in the populations studied (Brainerd and Patek, 1998; Spouge and Larkin, 1979), although the relationship between vertebral numbers and locomotory performance is complex.

\section{ACKNOWLEDGEMENTS}

We thank the curators L. Costeur (Naturhistorisches Museum, Basel) and E. Bernard (Natural History Museum, London) for access to important collections; C. Meyer from the Naturhistorisches Museum Basel, for important input at the beginning of the project on the geology of the localities with the studied fossils, and for information on collections at the Museum in Basel, and two anonymous reviewers who made useful suggestions we implemented. This project was supported by funding from the Swiss National Science Foundation (SNF) Sinergia program, granted to MRS-V, and a collab- oration with Walter Salzburger and Heinz Furrer (CRSII3-136293).

\section{REFERENCES}

Agassiz, L. 1839. De la famille des cyprinodontes, p. 4756. In Agassiz, L. (ed.), Recherches sur les poissons fossiles. Tome V(2). Petitpierre, Neuchâtel. (In French)

Aguirre, W.E., Walker, K., and Gideon, S. 2014. Tinkering with the axial skeleton: vertebral number variation in ecologically divergent threespine stickleback populations. Biological Journal of the Linnean Society, 113:204-219.

Barriga, J.P., Milano, D., and Cussac, V.E. 2013. Variation in vertebral number and its morphological implication in Galaxias platei. Journal of Fish Biology, 83:1321-1333.

Barton, D.G. and Wilson, M.V.H. 1999. Microstratigraphic study of meristic variation in an Eocene fish from a 10 000-year varved interval at Horsefly, British Columbia. Canadian Journal of Earth Science, 36:2059-2072.

Baumann, H., Rosales Casián, J.A., and Conover, D.O. 2012. Contrasting latitudinal variations in vertebral number and sex determination in Pacific versus Atlantic silverside fishes. Copeia, 2012:341-350.

Behrensmeyer, A.K. 1982. Time resolution in fluvial vertebrate assemblages. Paleobiology, 8:211-227.

Bell, M.A., Baumgartner, J.V., and Olson, E.C. 1985. Patterns of temporal change in single morphological characters of a Miocene stickleback fish. Paleobiology, 11:258-271.

Bell, M.A. and Haglund, T.R. 1982. Fine-scale temporal variation of the Miocene sticklebak Gasterosteus doryssus. Paleobiology, 8:282-292.

Bell, M.A. and Legendre, P. 1987. Multicharacter chronological clustering in a sequence of fossil sticklebacks. Systematic Zoology, 36:52-61.

Bever, G.S., Brusatte, S.L., Balanoff, A.M., and Norell, M.A. 2011. Variation, variability, and the origin of the avian endocranium: Insights from the anatomy of Alioramus altai (Theropoda: Tyrannosauroidea). PLOS ONE, 6(8):e23393.

Bird, N.C. and Mabee, P.M. 2003. Developmental morphology of the axial skeleton of the zebrafish, Danio rerio (Ostariophysi: Cyprinidae). Developmental Dynamics, 228:337-357.

Bookstein, F.L., Gingerich, P.D., and Kluge, A.G. 1978. Hierarchical linear modeling of the tempo and mode of evolution. Paleobiology, 4:120-134.

Brainerd, E.L. and Patek, S.N. 1998. Vertebral column morphology, C-start curvature and the evolution of mechanical defenses in tetraodontiform fishes. Copeia, 1998:971-984.

Bush, A., Powell, M.G., Arnold, W.S., Bert, T.M., and Daley, G.M. 2002. Time-averaging, evolution and morphological variation. Paleobiology, 28:9-25.

Chernoff, B. and Hall, H. D. 1979. Meristic and Morphometric Characters of a Population of Lucania parva 
(Pisces: Cyprinodontidae) Isolated in False River, Louisana. The Southwestern Naturalist, 24:181-185.

Cloutier, R. 1997. Morphologie et variations du toit crânien du dipneuste Scaumenacia curta (Whiteaves)(Sarcopterygii), du Dévonien supérieur du Québec. Geodiversitas, 19:61-105. (In French)

Cloutier, R., Caron, A., Grünbaum, T., and Le François, N.R. 2010. Effect of water velocity on the timing of skeletogenesis in the arctic charr, Salvelinus alpinus (Salmoniformes: Teleostei): an empirical case of developmental plasticity. International Journal of Zoology, 2010:1-16.

Costa, W.J.E.M. 2010. Historical biogeography of cynolebiasine annual killifishes inferred from dispersal-vicariance analysis. Journal of Biogeography, 37:1995-2004.

Costa, W.J.E.M. 2011. Comparative morphology, phylogenetic relationships, and historical biogeography of plesiolebiasine seasonal killifishes (Teleostei: Cyprinodontiformes: Rivulidae). Zoological Journal of the Linnean Society, 162:131-148.

Costa, W.J.E.M. 2012. Oligocene killifishes (Teleostei: Cyprinodontiformes) from southern France: relationships, taxonomic position, and evidence of internal fertilization. Vertebrate Zoology, 62:371-386.

De Baets, K., Klug, C., and Monnet, C. 2013. Intraspecific variability through ontogeny in early ammonoids. Paleobiology, 39:75-94.

Doadrio, I., Carmona, J.A., and Fernández-Delgado, C. 2002. Morphometric study of the Iberian Aphanius (Actinopterygii, Cyprinodontiformes), with description of a new species. Folia Zoologica, 51(1):67-79.

Ferrito, V., Maltagliati, F., Mauceri, A., Adorno, A., and Tigano, C. 2003. Morphological and genetic variation in four Italian populations of Lebias fasciata (Teleostei, Cyprinodontidae). Italian Journal of Zoology, 70(2):115-121.

Ferrito, V., Mannino, M.C., Pappalardo, A.M., and Tigano, C. 2007. Morphological variation among populations of Aphanius fasciatus Nardo, 1827 (Teleostei, Cyprinodontidae) from the Mediterranean. Journal of Fish Biology, 70:1-20.

Fischer-Rousseau, L., Cloutier, R., and Zelditch, M.L. 2009. Morphological integration and developmental progress during fish ontogeny in two contrasting habitats. Evolution and Development, 11:740-53.

Fitzsimons, J.M. 1979. Status of the nominal species of the fish genus Xenoophorus (Goodeidae, Cyprinodontiformes) from Mexico. Occasional Papers of the Museum of Zoology, Louisiana State University, 51:118.

Foth, C. and Rauhut, O.W.M. 2013. The good, the bad, and the ugly: The influence of skull reconstructions and intraspecific variability in studies of cranial morphometrics in theropods and basal saurischians. PLOS ONE, 8(8):e72007.

Freitas, R., Zhang, G., and Cohn, M.J. 2006. Evidence that mechanisms of fin development evolved in the midline of early vertebrates. Nature, 442:1033-1037.
Game, E.T. and Caley, M.J. 2006. The stability of $P$ in coral reef fishes. Evolution, 60:814-823.

García, G., Loureiro, M., Berois, N., Arezo, M.J., Casanova, G., Clivio, G., and Olivera, A. 2009. Pattern of differentiation in the annual killifish genus Austrolebias (Cyprinodontiformes; Rivulidae) from a biosphere reserve site in South America: a multidisciplinary approach. Biological Journal of the Linnean Society, 98:620-635.

Gaudant, J. 1978. Sur les conditions de gisement de lichthyofaune Oligocène d`Aix-en-Provence (Bouche-du-Rhone): Essai de définition d’un modèle paléoécologique et paléogéographique. Géobios, 11:393-397. (In French)

Gaudant, J. 1981a. Un nouveau Cyprinodontidae (poisson téléostéen) de l'Oligocène inférieur de Kleinkems (Pays de Bade, Allemagne): Prolebias rhenanus nov. sp. Sciences géologique Bulletin, 34:3-12. (In French)

Gaudant, J. 1981b. Mise au point sur l'ichthyofaune oligocène des anciennes plâtrières d'Aix-en-Provence (Bouch-du-Rhône). Note de Jean Gaudant, présentée par Jean Priveteau. Comptes rendus de l'Académie des Sciences Paris, 292 (20):1109-1112. (In French)

Gaudant, J. 2009. Occurrence of the genus Aphanius Nardo (Cyprinodontid fishes) in the Lower Miocene of the Cheb Basin (Czech Republic), with additional notes on Prolebias egeranus Laube. Journal of the National Museum (Prague), Natural History Series, 177(8):83-90.

Gaudant, J. 2012. Révision de Prolebias stenoura Sauvage, 1874 du Stampien (=Rupélien) de Limagne (centre de la France), espèce type du genre Prolebias (poisson téléostéen, Cyprinodontiformes). Geodiversitas, 34:409-423. (In French)

Gaudant, J. 2013. Occurrence of poeciliid fishes (Teleostei, Cyprinodontiformes) in the European OligoMiocene: the genus Paralebias nov. gen. Neues Jahrbuch für Geologie und Paläontologie Abhandlung, 267:215-222.

Giraud, J. 1902. Etudes géologique sur la Limagne (Auvergne). Bulletin du Service de la Carte géologique de France, 13(87):410. (In French)

Gorin, G. 1975. Etude palynostratigraphique des sédiments paléogènes de la Grande Limagne (Massif central). Bulletin du Bureau de Recherche géologique minière,1:147-181. (In French)

Goswami, A., Smaers, J.B., Soligo, C., and Polly, P.D. 2014. The macroevolutionary consequences of phenotypic integration: from development to deep time. Philosophical Transactions of the Royal Society B, 369:20130254.

Grande, L. 2010. An empirical synthetic pattern study of gars (Lepisosteiformes) and closely related species, based mostly on skeletal anatomy. The resurrection of Holostei. Copeia, 10(2A):1-871.

Grande, L. and Bemis, W.E. 1998. A comparative phylogenetic study of amiid fishes (Amiidae) based on 
comparative skeletal anatomy. An empirical search for interconnected patterns of natural history. Society of Vertebrate Paleontology Memoir, 18:1-696.

Grünbaum, T., Cloutier, R., and Vincent, B. 2012. Dynamic skeletogenesis in fishes: insight of exercise training on developmental plasticity. Developmental Dynamics, 241:1507-1524.

Hallgrímsson, B. and Hall, B.K. 2005. Variation: A Central Concept in Biology. Elsevier, Amsterdam.

Hammer, Ø., Harper, D.A.T., and Ryan, P.D. 2001. PAST: Paleontological statistics software package for education and data analysis. Palaeontologia Electronica 4.1.4:1-9 palaeo-electronica.org/2001_1/past/issue1_01.htm

Hice, L.A., Duffy, T.A., Munch, S.B., and Conover, D.O. 2012. Spatial scale and divergent patterns of variation in adapted traits in the ocean. Ecology Letters, 15:568-575.

Hohenegger, J. and Tatzreiter, F. 1992. Morphometric methods in determination of ammonite species, exemplified through Balatonites shells (Middle Triassic). Journal of Paleontology, 66:801-816.

Hopkins, J.M. 2011. How species longevity, intraspecific morphological variation and geographic range size are related: A comparison using Late Cambrian trilobites. Evolution, 65-11:3253-3273. doi:10.1111/ j.1558-5646.2011.01379.x

Hubbs, C.L. and Lagler, K.F. 1964. Fishes of the Great Lakes region (second edition). University of Michigan Press, Ann Arbor, Michigan.

Hubbs, C.L. and Miller, R.R. 1965. Studies of cyprinodont fishes. XXII. Variation in Lucania parva, its establishment in western United States, and description of a new species from an interior basin in Coahuila, Mexico. Miscellaneous Publications, Museum of Zoology, University of Michigan, 127:1-115.

Hughes, N.C. and Labandeira, C.C.1995. The stability of species in taxonomy. Paleobiology, 21:401-403.

Hunt, G. 2004a. Phenotypic variation in fossil samples: modeling the consequences of time-averaging. Paleobiology, 30:426-443.

Hunt, G. 2004b. Phenotypic variance inflation in fossil samples: an empirical assessment. Paleobiology, 30:487-506.

Hunt, G. 2007. Variation and early evolution. Science, 317:459-460. doi:10.1126/science. 1145550

Itazawa, Y. 1963. The ossification sequences of the vertebral column in the carp and the snake-head fish. Bulletin of the Japanese Society of Scientific Fisheries, 29:667-674.

Korn, D. and Klug, C. 2007. Conch form analysis, variability, morphological disparity, and mode of life of the Frasnian (Late Devonian) ammonoid Manticoceras from Coumiac (Montagne Noire, France), p. 57-85. In Landman, N.H., Davis, R.A., and Mapes, R.H. (eds.), Cephalopods Present and Past: New Insights and Fresh Perspectives. Springer, Dordecht.

Labandeira, C.C. and Hughes, N.C. 1994. Biometry of the Late Cambrian trilobite genus Dikelocephalus and its implications for trilobite systematics. Journal of Paleontology, 68:92-517.

Lane, N.G. 1963. Meristic variation in the dorsal cup of monobathrid camerate crinoids. Journal of Paleontology, 37(4):917-930.

Langerhans, R.B., Gifford, M.E., Domínguez-Domínguez, O., García-Bedoya, D., and DeWitt, T.J. 2012. Gambusia quadruncus (Cyprinodontiformes: Poeciliidae): a new species of mosquitofish from east-central México. Journal of Fish Biology, 81:1514-1539.

Lazzari, V., Aguilar, J.P., and Michaux J. 2010. Intraspecific variation and micro-macroevolution connection: illustration with late Miocene genus Progonomys (Rodentia, Muridae). Paleobiology, 36:641-657.

Lindsey, C.C. 1975. Pleomerism, the widespread tendency among related fish species for vertebral number to be correlated with maximum body length. Journal of the Fisheries Research Board of Canada, 32(12):2453-2469.

Lindsey, C.C. 1988. Factors controlling meristic variation, p. 197-274. In Hoar, W.S. and Randall, D.J. (eds.), Fish Physiology Volume XI-B. Academic Press, New York.

Lutz, H. 1997. Taphozönosen terrestrischer Insekten in aquatischen Sedimenten - ein Beitrag zur Rekonstruktion des Paläoenvironments. Neues Jahrbuch der Geologie und Paläontologie Abhandlungen, 203:173-210. (In German)

MacFadden, B.J. 1989. Dental character variation in paleopopulations and morphospecies of fossil horses and extant analogs, p. 128-141. In Prothero, D.R. and Schoch, R.M. (eds.), The Evolution of Perissodactyls. Oxford University Press, New York.

MacFadden, B.J. 1997. Pleistocene horse from Tarija, Bolivia, and validity of the genus †Onohippidium (Mammalia: Equidae). Journal of Vertebrate Paleontology, 17(1):199-218.

MacGregor, R.B. and MacCrimmon, H.R. 1977. Evidence of genetic and environmental influences on meristic variation in the rainbow trout, Salmo gairdneri Richardson. Environmental Biology of Fishes, 2:25-33.

Maltagliati, F., Domenici, P., Franch Fosch, C., Cossu, P., Casu, M., and Castelli, A. 2003. Small-scale morphological and genetic differentiation in the Mediterranean killifish, Aphanius fasciatus (Cyprinodontidae), from a coastal brackish-water pond and an adjacent pool in Northern Sardinia (Italy). Oceanologica Acta, 26:111-119.

Maxwell, E.E. 2012. Unraveling the influences of soft-tissue flipper development on skeletal variation using an extinct taxon. Journal of Experimental Zoology (Molecular and Developmental Evolution), 318:545554.

Maxwell, E.E. and Dececchi, T.A. 2013. Ontogeny and stratigraphy influence observed phenotypic integration in the limb skeleton of a fossil tetrapod. Paleobiology, 39:123-134. 
Maxwell, E.E. and Wilson, L.A.B. 2013. Regionalization of the axial skeleton in the 'ambush predator' guild are there developmental rules underlying body shape evolution in ray-finned fishes? BMC Evolutionary Biology, 13:265.

Mayr, E. 1963. Animal Species and Evolution. Belknap Press, Harvard.

McCoy, M.W., Bolker, B.M., Osenberg, C.W., Miner, B.G., and Vonesh, J.R. 2006. Size correction: comparing morphological traits among populations and environments. Oecologia, 148:547-554.

McCune, A.R. 1990. Evolutionary novelty and atavism in the Semionotus Complex: relaxed selection during colonization of an expanding lake. Evolution, 44:7185.

McCune, A.R. 1996. Biogeographic and stratigraphic evidence for rapid speciation in semionotid fishes. Paleobiology, 22:34-48.

McDowall, R.M. 2003. Variation in vertebral number in galaxiid fishes (Teleostei: Galaxiidae): a legacy of life history, latitude and length. Environmental Biology of Fishes, 66:361-381.

Mehta, R.S., Ward, A.B., Alfaro, M.E., and Wainwright, P.C. 2010. Elongation of the body in eels. Integrative and Comparative Biology, 50:1091-1105.

Meyer, D.L. and Ausich, W.I. 1997. Morphologic variation within and among populations of the Camerate Crinoid Agaricocrinus (Lower Mississippian, Kentucky and Tennessee): Breaking the spell of the Mushroom. Journal of Paleontology, 71:896-917.

Micklich, N. and Klappert, G. 2004. Character variation in some Messel fishes, p.137-163. In Arratia, G. and Tintori, A. (eds.), Mesozoic Fishes 3 - Systematics, Paleoenvironments and Biodiversity. Verlag Dr. Friedrich Pfeil, München, Germany.

Mieg, M. 1892. Excursions géologiques en Alsace et dans les pays voisins. Une excursion à KleinkemsIstein. Feuille des Jeunes Naturalists, $23^{e}$ année (1892-1893):20-31. (In French)

Monnet, C., Bucher, H., Wasmer, W., and Guex, J. 2010. Revision of the genus Acrochordiceras Hyatt, 1877 (Ammonoidea, Middle Triassic): morphology, biometry, biostratigraphy and intraspecific variability. Palaeontology, 53:961-996.

Nagiec, C. 1977. Ossification of the axial skeleton and fins in the whitefish, Coregonus lavaretus L. Acta Biologica Cracoviensia Series Zoologia, 20:155-179.

Nelson, J.E. 2006. Fishes of the World (fourth edition). Wiley and Sons, Hoboken.

Parenti, L. and Tigano, C. 1993. Polymorphic skeletal characters in Aphanius fasciatus (Teleostei: Cyprinodontiformes). Copeia, 4:1132-1137.

Pécoil, R. 1938. Etudes stratigraphique des terrains Oligocènes du massif du Puy Saint-Romain (Limagne d`Auvergne). Revue des Sciences naturelles d'Auvergne, 4(2):68-82. (In French)

Petry, D. 1982. The pattern of phyletic speciation. Paleobiology, 8:56-66.
Raath, M.A. 1990. Morphological variation in small theropods and its meaning in systematics: evidence from Syntarsus rhodesiensis, p. 91-105. In Carpenter, K. and Currie, P.J. (eds.), Dinosaur Systematics: Approaches and Perspectives. Cambridge University Press, Cambridge.

Reichenbacher, B., Sienknecht, U., Küchenhoff, H., and Fenske, N. 2007. Combined otolith morphology and morphometry for assessing taxonomy and diversity in fossil and extant Killifishes (Aphanius, †Prolebias). Journal of Morphology, 268:898-915.

Reichenbacher, B. and Reichard, M. 2014. Otoliths of five extant species of the annual Killifish Nothobranchius from the East African savannah. PLoS ONE, 9(11):e112459. doi:10.1371/journal.pone.0112459

Renaud, S., Auffray, J.C., and Michaux, J. 2006. Conserved phenotypic variation patterns, evolution along lines of least resistance, and departure due to selection in fossil rodents. Evolution, 60:1701-1717.

Sauvage, H.E. 1874. Notice sur les poisons tertiaires d’Auvergne. Bulletin de la Société d'Histoire naturelle de Toulouse, 8:171-198. (In French)

Schaeffer, B., Hecht, M.K., and Eldredge, N. 1972. Phylogeny and paleontology. Evolutionary Biology, 6:3146.

Shikano, T. and Merilä, J. 2011. Body size and the number of vertebrae in the nine-spined stickleback (Pungitius pungitius). Biological Journal of the Linnean Society, 104:378-385.

Simpson, G.G. 1953. The Major Features of Evolution. Columbia University Press, New York.

Smith, G.R. 1987. Fish speciation in a western North American Pliocene rift lake. Palaios, 2:436-445.

Spouge, J.L. and Larkin, P.A., 1979. A reason for pleomerism. Journal of the Fisheries Research Board of Canada, 36:255-269.

Tigano, C. and Ferrito, V. 1984. Studio biometrico e morfologico di Aphanius fasciatus Nardo dell'Adriatico e di Sicilia (Pisces,Cyprinodontidae). Nova Thalassia, 6:679-680. (In Italian)

Tigano, C. and Ferrito, V. 1985. Studio osteológico comparato del cranio di popolazioni di Aphanius fasciatus Nardo (Pisces, Cyprinodontidae) dell'Adriatico e di fiumi della Sicilia. Animalia, 12:13-57. (In Italian)

Tigano, C., Ferrito, V., Adorno, A., Mannino, M.C., and Mauceri, A. 2001. Pharyngeal and oral jaw differentiation in five populations of Aphanius fasciatus (Teleostei, Cyprinodontidae). Italian Journal of Zoology, 68:201-206.

Tigano, C., Ferrito, V., and Nicosia, R. 1999. Morphological analysis of the pharyngeal jaws in two populations of Aphanius fasciatus Valenciennes, 1821 (Teleostei: Cyprinodontidae). Journal of Morphology, 241:107-114.

Ward, A.B. and Mehta, R.S. 2010. Axial elongation in fishes: using morphological approaches to elucidate developmental mechanisms in studying body shape. Integrative and Comparative Biology, 50:1106-1119. 
Ward, A.B. and Mehta, R.S. 2014. Differential occupation of axial morphospace. Zoology, 117:70-76.

Webb, P.W. 1984. Body form, locomotion and foraging in aquatic vertebrates. American Zoologist, 24:107-120.

Webster, M. 2007. A Cambrian peak in morphological variation within trilobite species. Science, 317:499502.

Webster, M. 2014. Ontogeny and intraspecific variation of the early Cambrian trilobite Olenellus gilberti, with implications for olenelline phylogeny and macroevolutionary trends in phenotypic canalization. Journal of Systematic Palaeontology, 13:1-74. doi:10.1080/ 14772019.2013.852903

Wilson, L.A.B. 2013. The contribution of developmental palaeontology to extensions of evolutionary theory.
Acta Zoologica, 94:254-260. doi:10.1111/j.14636395.2011.00539.x

Winkler, J.D., Stölting, K.N., and Wilson, A.B. 2012. Sexspecific responses to fecundity selection in the broad-nosed pipefish. Evolutionary Ecology, 26:701714.

Yamahira, K., Lankford Jr., T.E., and Conover, D.O. 2006. Intra- and interspecific latitudinal variation in vertebral number of Menidia spp. (Teleostei: Atherinopsidae). Copeia, 2006:431-436.

Yamahira, K. and Nishida, T. 2009. Latitudinal variation in axial patterning of the medaka (Actinopterygii: Adrianichthyidae): Jordan's rule is substantiated by genetic variation in abdominal vertebral number. Biological Journal of the Linnean Society, 96:856-866. 
FREY, MAXWELL, \& SÁNCHEZ-VILLAGRA: FOSSIL KILLIFISHES FROM EUROPE

\section{APPENDIX}

Meristic and morphometric data collected for this study.

\begin{tabular}{|c|c|c|c|c|c|c|c|c|c|c|c|c|c|}
\hline $\begin{array}{l}\stackrel{0}{0} \\
\frac{\pi}{0} \\
\text { के }\end{array}$ & $\begin{array}{l}\bar{\Phi} \\
\frac{\Xi}{0} \\
\Phi \\
\text { के }\end{array}$ & 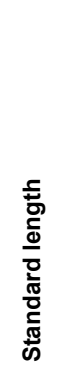 & 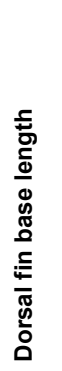 & 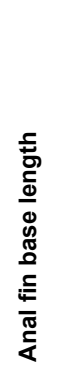 & 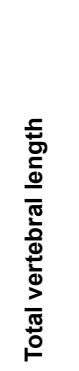 & 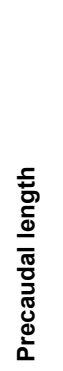 & 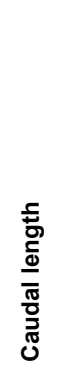 & 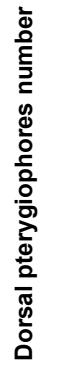 & 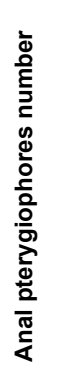 & 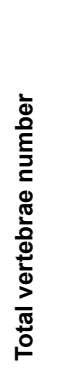 & 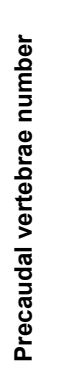 & 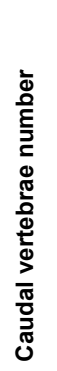 & 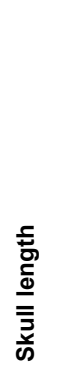 \\
\hline \multirow[t]{29}{*}{ Prolebias rhenanus } & Ru99 & 29.2 & 3.5 & 3.4 & 19.8 & 9.1 & 10.7 & 10 & 11 & 29 & 12 & 17 & 9.4 \\
\hline & Ru91 & 28 & 3.5 & 3.2 & $?$ & $?$ & 10.4 & 11 & 12 & $?$ & $?$ & 16 & $?$ \\
\hline & Ru24 & 26.8 & $?$ & $?$ & 18.8 & 8.8 & 10 & $?$ & $?$ & 28 & 11 & 17 & 8 \\
\hline & Ru8 & 13.9 & $?$ & $?$ & $?$ & $?$ & 5.6 & $?$ & $?$ & $?$ & $?$ & 16 & $?$ \\
\hline & Ru1 & 16.9 & $?$ & 2.9 & 13.5 & 5.6 & 7.9 & $?$ & 11 & 28 & 12 & 16 & 3.4 \\
\hline & Ru61 & 23.1 & 2.8 & 3.3 & 16.4 & 7.4 & 9 & 9 & 11 & 30 & 12 & 18 & 6.7 \\
\hline & Ru62 & 24.9 & $?$ & 2.9 & $?$ & $?$ & 9.5 & $?$ & 12 & $?$ & $?$ & 17 & $?$ \\
\hline & Ru63 & 27.8 & $?$ & $?$ & $?$ & $?$ & 11.1 & $?$ & $?$ & $?$ & $?$ & 17 & $?$ \\
\hline & Ru64 & 23.2 & 2.9 & 3.6 & 17.1 & $?$ & $?$ & 10 & 12 & 28 & $?$ & $?$ & 6.1 \\
\hline & Ru65 & 23.5 & 3 & 4.1 & 16.8 & 7 & 9.8 & 11 & 10 & 29 & 12 & 17 & 6.7 \\
\hline & Ru67 & 29.5 & 3.6 & 3.7 & 20.3 & 9.8 & 10.5 & 11 & 12 & 28 & 11 & 17 & 9.2 \\
\hline & Ru70 & 23.3 & $?$ & $?$ & 17.4 & $?$ & $?$ & $?$ & $?$ & 27 & $?$ & $?$ & 5.9 \\
\hline & Ru73 & 30.5 & $?$ & 3.7 & $?$ & $?$ & 12.2 & $?$ & 11 & $?$ & $?$ & 16 & $?$ \\
\hline & Ru80 & 25.6 & 3.3 & 3.1 & 18.4 & 8.8 & 9.6 & 11 & 13 & 29 & 12 & 17 & 7.2 \\
\hline & Ru82 & 21.9 & 2.7 & 2.9 & 15.5 & 6 & 9.5 & 10 & 9 & 28 & 12 & 16 & 6.4 \\
\hline & Ru95 & 23 & 3 & 3.1 & 17.6 & 8.2 & 9.4 & 10 & 10 & 29 & 12 & 17 & 5.4 \\
\hline & Ru115 & 22.5 & 3.2 & 4.1 & $?$ & $?$ & 9.5 & 11 & 12 & $?$ & $?$ & 16 & $?$ \\
\hline & Ru87 & 22.7 & $?$ & 2.8 & $?$ & $?$ & 9.5 & $?$ & 11 & $?$ & $?$ & 16 & $?$ \\
\hline & Ru89 & 22.9 & 2.9 & 3.5 & $?$ & $?$ & 9.6 & 10 & 12 & $?$ & $?$ & 16 & $?$ \\
\hline & Ru90 & 19.2 & $?$ & $?$ & $?$ & $?$ & 8.6 & $?$ & $?$ & $?$ & $?$ & 17 & $?$ \\
\hline & Ru92 & 31.6 & $?$ & 4 & $?$ & $?$ & 12.3 & $?$ & 10 & $?$ & $?$ & 17 & $?$ \\
\hline & Ru96 & 20 & $?$ & $?$ & $?$ & $?$ & 8.6 & $?$ & $?$ & $?$ & $?$ & 16 & $?$ \\
\hline & Ru98 & 23.4 & 3 & 3.1 & $?$ & $?$ & 9.8 & 12 & 12 & $?$ & $?$ & 17 & $?$ \\
\hline & Ru100 & 19.8 & 2.4 & 3.5 & 15.6 & 6.6 & 9 & 9 & 12 & 27 & 11 & 16 & 4.2 \\
\hline & Ru102 & 24.2 & 3.4 & 3.3 & 16.9 & 7 & 9.9 & 11 & 11 & 29 & 12 & 17 & 7.3 \\
\hline & Ru107 & 25.5 & $?$ & 3.1 & $?$ & $?$ & 10.9 & $?$ & 11 & $?$ & $?$ & 17 & $?$ \\
\hline & Ru111 & 14.3 & 2.3 & $?$ & 10.1 & 4 & 6.1 & 10 & $?$ & 29 & 12 & 17 & 4.2 \\
\hline & Ru113 & 23.3 & 3.5 & 3.7 & 18.3 & 7.7 & 10.6 & 11 & 10 & 29 & 12 & 17 & 5 \\
\hline & Ru116 & 27.1 & $?$ & 3.3 & $?$ & $?$ & 10.7 & $?$ & 11 & $?$ & $?$ & 16 & $?$ \\
\hline
\end{tabular}




\begin{tabular}{|c|c|c|c|c|c|c|c|c|c|c|c|c|c|}
\hline 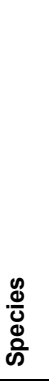 & 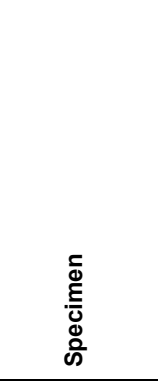 & 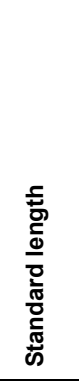 & 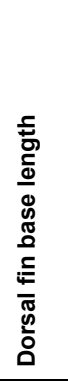 & 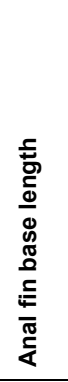 & 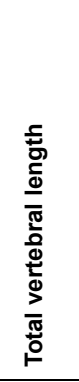 & 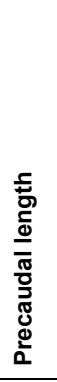 & 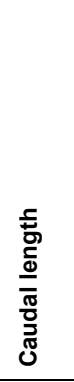 & 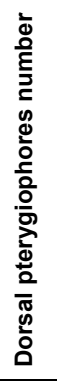 & 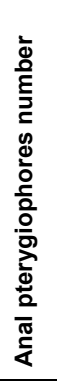 & 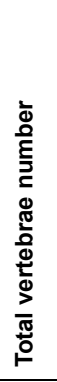 & 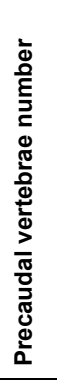 & 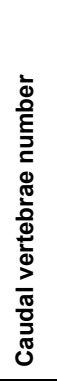 & 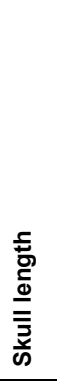 \\
\hline & DSC4221 & 25.9 & $?$ & $?$ & 18 & 7.9 & 10.1 & $?$ & $?$ & $?$ & $?$ & 16 & 7.9 \\
\hline & Ru74 & 24.9 & $?$ & 3.2 & 18.9 & 8.5 & 10.4 & $?$ & 11 & 28 & 12 & 16 & 6 \\
\hline & Ru173 & 22.8 & 2.7 & 3.4 & $?$ & $?$ & 9.6 & 10 & 11 & $?$ & $?$ & 17 & $?$ \\
\hline & Ru3 & 25.2 & 3.3 & 3.9 & 18.3 & 7.5 & 10.8 & 11 & 11 & 29 & 12 & 17 & 6.9 \\
\hline & Ru4 & 23.1 & 2.9 & 3.2 & $?$ & $?$ & 9.8 & 10 & 10 & $?$ & $?$ & 17 & $?$ \\
\hline & Ru7 & 14.1 & $?$ & $?$ & $?$ & $?$ & 6.2 & $?$ & $?$ & $?$ & $?$ & 17 & $?$ \\
\hline & Ru11 & 22.4 & $?$ & $?$ & 14.6 & 5.6 & 9 & $?$ & $?$ & 29 & 12 & 17 & 7.8 \\
\hline & Ru12 & 19 & 2.2 & 3.1 & $?$ & $?$ & 8.5 & 10 & 11 & $?$ & $?$ & 18 & $?$ \\
\hline & Ru16 & 26 & 2.9 & 3.1 & $?$ & $?$ & 10.2 & 10 & 11 & $?$ & $?$ & 17 & $?$ \\
\hline & Ru13 & 22 & 2.8 & 3.8 & 16.6 & 6.9 & 9.7 & 8 & 11 & 28 & 12 & 16 & 5.4 \\
\hline & Ru17 & 23.9 & 3.1 & 3.9 & 17.4 & 6.9 & 10.5 & 10 & 11 & 29 & 12 & 17 & 6.5 \\
\hline & Ru18 & 22.2 & $?$ & $?$ & 17.6 & 8 & 9.6 & $?$ & $?$ & 28 & 12 & 16 & 4.6 \\
\hline & Ru19 & 22.1 & 2.9 & 3.1 & $?$ & $?$ & 9.8 & 9 & 11 & 28 & $?$ & $?$ & $?$ \\
\hline & Ru25 & 22.6 & 2.8 & 2.6 & $?$ & $?$ & $?$ & 10 & 11 & $?$ & $?$ & $?$ & $?$ \\
\hline & Ru27 & 21.6 & $?$ & $?$ & $?$ & $?$ & 9.6 & $?$ & $?$ & $?$ & $?$ & 17 & $?$ \\
\hline & Ru30 & 26.9 & $?$ & 3.2 & 18.5 & 7.5 & 11 & $?$ & 11 & 29 & 12 & 17 & 8.4 \\
\hline & Ru34 & 22.9 & 3 & 3.2 & 15 & $?$ & $?$ & 10 & 11 & 28 & $?$ & $?$ & 7.9 \\
\hline & Ru46 & 23.9 & 3.1 & 2.7 & $?$ & $?$ & 11.2 & 10 & 9 & $?$ & $?$ & 18 & $?$ \\
\hline & Ru53 & 25.1 & 3.3 & $?$ & $?$ & $?$ & 10 & 11 & $?$ & $?$ & $?$ & 17 & $?$ \\
\hline & Ru56 & 18.9 & $?$ & $?$ & $?$ & $?$ & 9.1 & $?$ & $?$ & $?$ & $?$ & 17 & $?$ \\
\hline & Ru31 & 23.3 & $?$ & 2.9 & $?$ & $?$ & 9.9 & $?$ & 11 & $?$ & $?$ & 16 & $?$ \\
\hline & Ru33 & 23.9 & $?$ & $?$ & 17.1 & $?$ & $?$ & $?$ & $?$ & 29 & $?$ & $?$ & 6.8 \\
\hline & Ru26 & 23.9 & $?$ & $?$ & 17.7 & $?$ & $?$ & $?$ & $?$ & 28 & $?$ & $?$ & 6.2 \\
\hline & Ru23 & 19.9 & 2.5 & 3 & $?$ & $?$ & 8.5 & 10 & 12 & $?$ & $?$ & 16 & $?$ \\
\hline & Ru20 & 21.1 & 2.7 & 3.5 & $?$ & $?$ & 9.5 & 8 & 11 & $?$ & $?$ & 16 & $?$ \\
\hline & Ru66 & 33.5 & 3.1 & 4 & 24 & 12 & 12 & 9 & 11 & 28 & 12 & 16 & 9.5 \\
\hline & $\begin{array}{c}\mathrm{DSC} 4282= \\
1\end{array}$ & 23.1 & $?$ & $?$ & 17 & 7.5 & 9.5 & $?$ & $?$ & 29 & 12 & 17 & 6.1 \\
\hline & DSC4283 & 20.9 & 3 & 3.5 & $?$ & $?$ & 9.1 & 10 & 11 & $?$ & $?$ & 16 & $?$ \\
\hline & DSC4284 & 22.1 & $?$ & 3 & $?$ & $?$ & 9.9 & $?$ & 10 & $?$ & $?$ & 17 & $?$ \\
\hline & DSC4293 & 30 & 3 & 3.9 & $?$ & $?$ & 11.2 & 9 & 10 & 28 & $?$ & $?$ & $?$ \\
\hline & $\begin{array}{c}\text { DSC4295 }= \\
2\end{array}$ & 20.4 & $?$ & $?$ & 16.1 & 7 & 9.1 & $?$ & $?$ & 29 & 12 & 17 & 4.3 \\
\hline
\end{tabular}




\begin{tabular}{|c|c|c|c|c|c|c|c|c|c|c|c|c|c|}
\hline 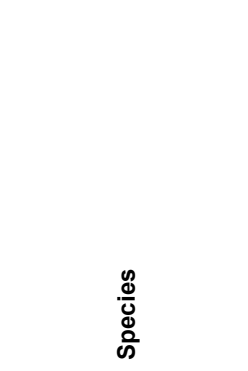 & 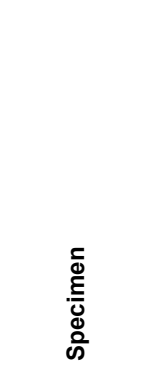 & 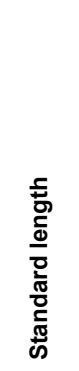 & 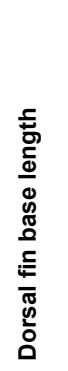 & 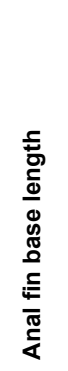 & 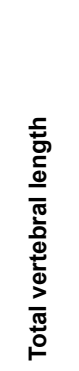 & 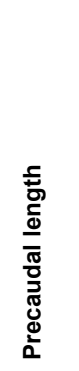 & 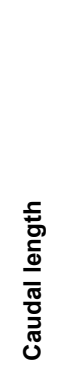 & 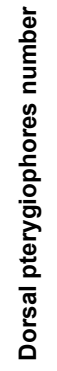 & 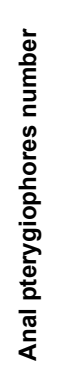 & 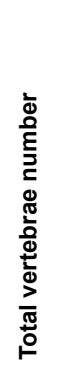 & 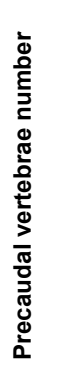 & 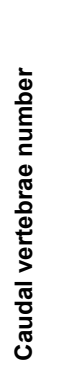 & 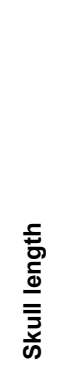 \\
\hline & $\begin{array}{c}\mathrm{DSC} 4299= \\
4\end{array}$ & 25.6 & $?$ & 2.9 & $?$ & $?$ & 10 & $?$ & 10 & $?$ & $?$ & 17 & $?$ \\
\hline & DSC4294 & 22.4 & 3.1 & 3.2 & $?$ & $?$ & 9.8 & 10 & 11 & $?$ & $?$ & 17 & $?$ \\
\hline \multirow[t]{29}{*}{ Prolebias stenoura } & $28491 n$ & 39.8 & 5.7 & 6.5 & 32.6 & 13.6 & 19 & 12 & 15 & 30 & 12 & 18 & 7.2 \\
\hline & 28491 & 35.3 & 4 & 5.4 & 26.6 & 10.1 & 16.5 & 13 & 15 & 31 & 12 & 19 & 8.7 \\
\hline & $28491 \mathrm{k}$ & 42 & $?$ & $?$ & 32.8 & 15.9 & 16.9 & $?$ & $?$ & 30 & 12 & 18 & 9.2 \\
\hline & 1908 & 34.1 & 6.8 & 4.4 & 25.7 & 9 & 16.7 & 16 & 15 & 30 & 12 & 18 & 8.4 \\
\hline & P57078 & 51 & 6.9 & 8.5 & 35.7 & 15.5 & 20.2 & 11 & 15 & 30 & 11 & 19 & 15.3 \\
\hline & P57069 & 40.5 & 5.2 & 5.3 & $?$ & $?$ & 16.4 & 14 & 15 & $?$ & $?$ & 19 & $?$ \\
\hline & P57068 & 27 & 3.2 & 4.1 & 20.4 & 7.5 & 12.9 & 12 & 15 & 30 & 12 & 18 & 6.6 \\
\hline & P57073 & 36 & 4 & 4.1 & 26.7 & 11 & 15.7 & 11 & 14 & 30 & 12 & 18 & 9.3 \\
\hline & P57063 & 27.1 & 3.5 & 3.4 & 19.6 & 7.9 & 11.7 & 12 & 14 & 30 & 12 & 18 & 7.5 \\
\hline & P57053 & 40.5 & $?$ & 5.1 & 29.1 & 11.5 & 17.6 & $?$ & 15 & 29 & 12 & 17 & 11.4 \\
\hline & P57057 & 33.3 & 3.9 & 3.5 & $?$ & $?$ & 14.1 & 13 & 15 & $?$ & $?$ & 18 & $?$ \\
\hline & P57059 & 41.4 & 4.3 & 4 & 31.4 & 12.8 & 18.6 & 11 & 13 & 31 & 12 & 19 & 10 \\
\hline & P57057b & 42.8 & 3.7 & 5.4 & 31.3 & 13.1 & 18.2 & 11 & 15 & 31 & 12 & 19 & 11.5 \\
\hline & P57058 & 36.9 & 4.4 & 4.8 & $?$ & $?$ & 16.7 & 13 & 15 & $?$ & $?$ & 18 & $?$ \\
\hline & $\mathrm{P} 1832 \mathrm{a}$ & 44.4 & 6.2 & 6.4 & 31.2 & 12 & 19.2 & 14 & 16 & 31 & 12 & 19 & 13.2 \\
\hline & P1832 & 45 & $?$ & 4.9 & 31 & 13.5 & 17.5 & $?$ & 15 & 30 & 12 & 18 & 14 \\
\hline & $\mathrm{P} 1832 \mathrm{~b}$ & 41.3 & 3.8 & 4.6 & $?$ & $?$ & 16.9 & 12 & 15 & $?$ & $?$ & 17 & $?$ \\
\hline & 21416 & 29.5 & $?$ & 3.9 & 21.2 & 8.4 & 12.8 & $?$ & 14 & 31 & 12 & 19 & 8.3 \\
\hline & $28491 \mathrm{~m}$ & 38.5 & 4 & 4.6 & 27.7 & 11.9 & 15.8 & 13 & 19 & 30 & 12 & 18 & 10.8 \\
\hline & 28491.1 & 37.1 & 4.1 & 3.8 & $?$ & $?$ & 15.1 & 12 & 15 & $?$ & $?$ & 18 & $?$ \\
\hline & 28491.2 & 39.2 & 4.2 & 4.9 & $?$ & $?$ & 15.7 & 12 & 13 & $?$ & $?$ & 17 & $?$ \\
\hline & 28491c & 29.3 & 3.7 & 3.7 & $?$ & $?$ & 12 & 14 & 15 & $?$ & $?$ & 18 & $?$ \\
\hline & $28491 \mathrm{~h}$ & 31.1 & $?$ & 2.3 & 22 & 9.2 & 12.8 & $?$ & 13 & 30 & 13 & 17 & 9.1 \\
\hline & $28491 \mathrm{~g}$ & 26.1 & $?$ & $?$ & $?$ & $?$ & 11 & $?$ & $?$ & $?$ & $?$ & 19 & $?$ \\
\hline & 28496.1 & 39.1 & 6.7 & 5.3 & 28 & 11.6 & 16.4 & 13 & 13 & 29 & 12 & 17 & 11.1 \\
\hline & 28496.3 & 33.2 & $?$ & 3.9 & 25.5 & 11.7 & 13.8 & $?$ & 14 & 29 & 12 & 17 & 7.7 \\
\hline & 28496.4 & 43 & $?$ & $?$ & 33.7 & 13.8 & 19.9 & $?$ & $?$ & 29 & 11 & 18 & 9.3 \\
\hline & 28491I & 31.5 & 4 & 3.7 & 22.8 & 9.6 & 13.2 & 14 & 14 & 30 & 12 & 18 & 8.7 \\
\hline & 284910 & 40 & 4.9 & $?$ & $?$ & $?$ & 17.2 & 14 & $?$ & $?$ & $?$ & 18 & $?$ \\
\hline
\end{tabular}




\begin{tabular}{|c|c|c|c|c|c|c|c|c|c|c|c|c|c|}
\hline 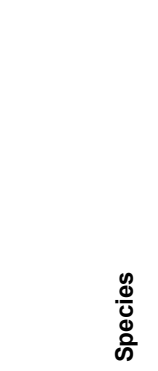 & 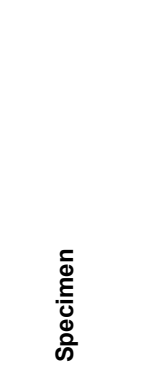 & 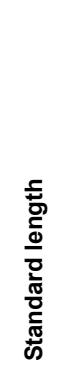 & 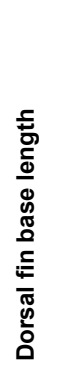 & 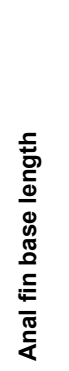 & 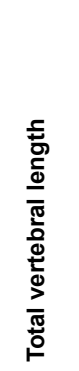 & 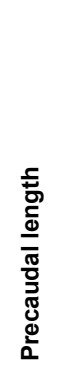 & 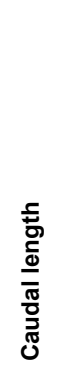 & 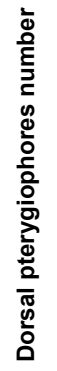 & 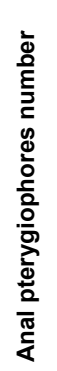 & 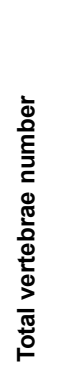 & 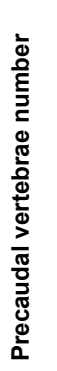 & 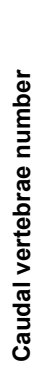 & 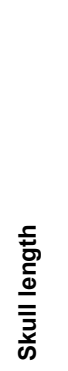 \\
\hline & $28491 p$ & 19.8 & 2.3 & $?$ & 14 & 5.7 & 8.3 & 12 & $?$ & 31 & 12 & 19 & 5.8 \\
\hline & $28491 r$ & 20.9 & $?$ & 2.6 & $?$ & $?$ & 9 & $?$ & 13 & $?$ & $?$ & 18 & $?$ \\
\hline & $28491 q$ & 21.8 & $?$ & 2.6 & 14.3 & 5.7 & 8.6 & $?$ & 14 & 29 & 12 & 17 & 7.5 \\
\hline & 28491s & 42 & 4.8 & 4.3 & 29.7 & 13 & 16.7 & 12 & 14 & 30 & 12 & 18 & 12.3 \\
\hline & $28491 u$ & 19 & $?$ & $?$ & 13.5 & 5 & 8.5 & $?$ & $?$ & 30 & 12 & 18 & 5.5 \\
\hline & $28491 v$ & 49.5 & $?$ & 6.5 & $?$ & $?$ & 19.2 & $?$ & 15 & $?$ & $?$ & 18 & $?$ \\
\hline & $28491 \mathrm{t}$ & 42.9 & 5 & 4.6 & 33.1 & 15.9 & 17.2 & 11 & 14 & 30 & 12 & 18 & 9.8 \\
\hline & P3851 & 35.6 & 4 & 4.3 & 24.9 & 9.8 & 15.1 & 11 & 15 & 30 & 12 & 18 & 10.7 \\
\hline & 21417 & 37.5 & 4.4 & 4.6 & $?$ & $?$ & 16 & 14 & 12 & $?$ & $?$ & 18 & $?$ \\
\hline \multirow{22}{*}{$\begin{array}{l}\text { Paralebias } \\
\text { cephalotes }\end{array}$} & $1831 a$ & 24.9 & 2.1 & 4.9 & $?$ & $?$ & 11.2 & 7 & 14 & $?$ & $?$ & 18 & $?$ \\
\hline & 43438 & 23.6 & 2.6 & 2.1 & 16.7 & 6.4 & 10.3 & 9 & 13 & 29 & 10 & 19 & 6.9 \\
\hline & 21397 & 24.3 & $?$ & 3.2 & 17.9 & 7.6 & 10.3 & $?$ & 10 & 30 & 12 & 18 & 6.4 \\
\hline & 21396.1 & 24 & 2.2 & 2.8 & 17.6 & 6.6 & 11 & 9 & 12 & 31 & 12 & 19 & 6.4 \\
\hline & 21396.2 & 24.9 & $?$ & 3.7 & 17.1 & 6 & 11.1 & $?$ & 16 & 29 & 10 & 19 & 7.8 \\
\hline & P.1831.1 & 31.2 & 3.1 & 3.5 & 23.4 & 8.5 & 14.9 & 9 & 12 & 30 & 10 & 20 & 7.8 \\
\hline & P.1831.2 & 22.8 & 2.2 & 3.2 & 16.8 & 6.8 & 10 & 10 & 13 & 31 & 12 & 19 & 6 \\
\hline & P.1831.3 & 26.7 & $?$ & 3.9 & 19.5 & 6.5 & 13 & $?$ & 12 & 30 & 10 & 20 & 7.2 \\
\hline & P.1831.4 & 28.1 & 2.6 & 3.9 & 20.6 & 6.9 & 13.7 & 8 & 13 & 30 & 10 & 20 & 7.5 \\
\hline & P.1831.5 & 26.9 & 2 & 3.5 & 18.6 & 6.1 & 12.5 & 7 & 14 & 30 & 10 & 20 & 8.3 \\
\hline & P.1831.8 & 22 & 2.9 & 2.8 & $?$ & $?$ & 9.5 & 9 & 14 & $?$ & $?$ & 19 & $?$ \\
\hline & P.1831.9 & 20.8 & $?$ & 2.6 & $?$ & $?$ & 9.6 & $?$ & 12 & $?$ & $?$ & 19 & $?$ \\
\hline & P.1831.12 & 23.2 & 1.9 & 2.7 & $?$ & $?$ & 10.7 & 7 & 13 & $?$ & $?$ & 20 & $?$ \\
\hline & P.1831.13 & 23.5 & $?$ & 2.9 & $?$ & $?$ & 11.7 & $?$ & 13 & $?$ & $?$ & 21 & $?$ \\
\hline & P.1831.14 & 23.3 & $?$ & 2.5 & 18.2 & 7.1 & 11.1 & $?$ & 11 & 32 & 11 & 21 & 5.1 \\
\hline & P.1831.16 & 22.2 & 2.1 & 3.9 & 17.5 & 5.8 & 11.7 & 9 & 14 & 30 & 10 & 20 & 4.7 \\
\hline & 20071.1 & 22 & 2.7 & 3 & 16.4 & 5.9 & 10.5 & 9 & $?$ & 30 & 11 & 19 & 5.6 \\
\hline & 20071.2 & 23.7 & $?$ & 2.9 & 17.4 & 6 & 11.4 & $?$ & 10 & 30 & 10 & 20 & 6.3 \\
\hline & 20071.6 & 21.2 & $?$ & $?$ & $?$ & $?$ & 10.3 & $?$ & $?$ & $?$ & $?$ & 20 & $?$ \\
\hline & 20071.10 & 23.7 & $?$ & 2.7 & 16.8 & 5.8 & 11 & $?$ & 12 & 29 & 10 & 19 & 6.9 \\
\hline & 20071.11 & 22.5 & $?$ & $?$ & 16.3 & 6.3 & 10 & $?$ & $?$ & 28 & 10 & 18 & 6.2 \\
\hline & 20071.12 & 28.9 & 3 & 3.7 & 21.3 & 8.1 & 13.2 & 10 & 13 & 30 & 11 & 19 & 7.6 \\
\hline
\end{tabular}




\begin{tabular}{|c|c|c|c|c|c|c|c|c|c|c|c|c|c|}
\hline 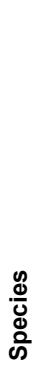 & 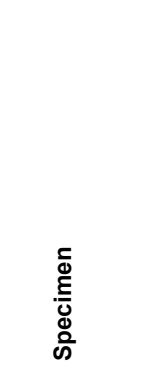 & 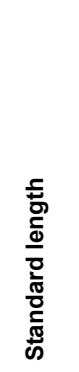 & 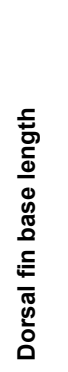 & 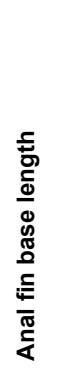 & 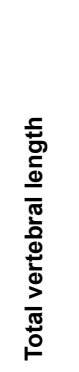 & 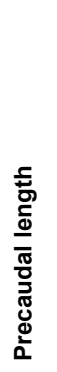 & 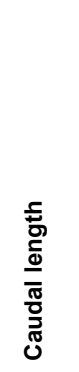 & 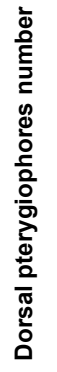 & 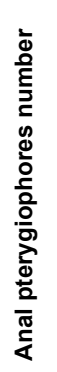 & 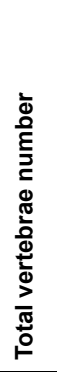 & 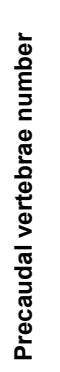 & 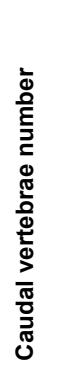 & 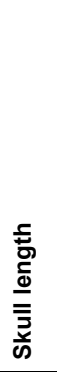 \\
\hline & 20071.14 & 21 & $?$ & 3.3 & 17.1 & 5.9 & 11.2 & $?$ & 13 & 30 & 10 & 20 & 3.9 \\
\hline & 20071.15 & 22.7 & 2.1 & 3.4 & $?$ & $?$ & 10.8 & 8 & 14 & $?$ & $?$ & 20 & $?$ \\
\hline & 20071.17 & 23.9 & $?$ & 3 & 16.9 & 6.3 & 10.6 & $?$ & 12 & 28 & 10 & 18 & 7 \\
\hline & 20071.19 & 23.4 & $?$ & 3.5 & 17.3 & 7.6 & 9.7 & $?$ & 14 & 29 & 12 & 17 & 6.1 \\
\hline & 20071.23 & 29.6 & 3 & 4.1 & 20.5 & 7.7 & 12.8 & 9 & 14 & 29 & 10 & 19 & 9.1 \\
\hline & 20071.30 & 32.5 & $?$ & 4.9 & $?$ & $?$ & 15.5 & $?$ & 12 & $?$ & $?$ & 20 & $?$ \\
\hline & 20071.29 & 23.1 & 2.2 & 3 & 17.8 & 7.5 & 10.3 & 9 & 12 & 28 & 11 & 17 & 5.3 \\
\hline & 20071.28 & 22.8 & $?$ & $?$ & 15.9 & 5.8 & 10.1 & $?$ & $?$ & 29 & 10 & 19 & 6.9 \\
\hline & 36131.1 & 28.8 & 2.3 & 3.9 & 21.7 & 8.6 & 13.1 & 8 & 14 & 29 & 11 & 18 & 7.1 \\
\hline & $36131 a$ & 25.1 & 2.1 & 3.7 & $?$ & $?$ & 11.8 & 8 & 14 & $?$ & $?$ & 19 & $?$ \\
\hline & 36131.2 & 24.7 & 2 & 3.4 & $?$ & $?$ & 12 & 8 & 13 & $?$ & $?$ & 19 & $?$ \\
\hline & 36131.5 & 20.9 & $?$ & $?$ & 15.4 & 4.9 & 10.5 & $?$ & $?$ & 30 & 11 & 19 & 5.5 \\
\hline & 36131.6 & 23.2 & 2 & 3.2 & 16.4 & 5.7 & 10.7 & 8 & 13 & 29 & 10 & 19 & 6.8 \\
\hline & 36131.8 & 26.4 & $?$ & 2.9 & 19.7 & 7.7 & 12 & $?$ & 12 & 29 & 11 & 18 & 6.7 \\
\hline & 36131.9 & 24.9 & 1.9 & 2.8 & 23.6 & 12 & 11.6 & 8 & 10 & 28 & 10 & 18 & 1.3 \\
\hline & 36131.10 & 25 & $?$ & $?$ & 17.8 & 7.1 & 10.7 & $?$ & $?$ & 28 & 10 & 18 & 7.2 \\
\hline & 36131.11 & 23.6 & $?$ & $?$ & 17.1 & 5.6 & 11.5 & $?$ & $?$ & 30 & 10 & 20 & 6.5 \\
\hline & 36131.12 & 26.5 & 4 & 2.7 & 19.2 & 6.7 & 12.5 & 9 & 12 & 30 & 10 & 20 & 7.3 \\
\hline & 36131.13 & 21.5 & 2.3 & 3 & 16.4 & 6 & 10.4 & 10 & 14 & 31 & 11 & 20 & 5.1 \\
\hline & 36131.14 & 23.8 & $?$ & 3.6 & 16.6 & 6.2 & 10.4 & $?$ & 14 & 30 & 10 & 20 & 7.2 \\
\hline & 36131.17 & 25 & $?$ & 3 & $?$ & $?$ & 11.1 & $?$ & 14 & $?$ & $?$ & 20 & $?$ \\
\hline & 36131.20 & 23.9 & 2.1 & 3.3 & 18.2 & 7 & 11.2 & 8 & 14 & 28 & 10 & 18 & 5.7 \\
\hline & 36131.23 & 23.9 & $?$ & 2.9 & 16.7 & 5.9 & 10.8 & $?$ & 12 & 28 & 10 & 18 & 7.2 \\
\hline & 36131.25 & 25.9 & 2.4 & 3.3 & 18.2 & 6.7 & 11.5 & 8 & 12 & 29 & 10 & 18 & 7.7 \\
\hline & 36131.26 & 23.9 & $?$ & 4 & $?$ & $?$ & 12.1 & $?$ & 14 & $?$ & $?$ & 20 & $?$ \\
\hline & 36131.27 & 24.2 & 1.7 & 2.4 & 18.6 & 7.8 & 10.8 & 8 & 12 & 29 & 10 & 19 & 5.6 \\
\hline & 36131.29 & 26.5 & $?$ & 3.6 & 19.9 & 7.3 & 12.6 & $?$ & 10 & 28 & 10 & 18 & 6.6 \\
\hline & 36131.28 & 24 & $?$ & 2.5 & 16.2 & 6.4 & 9.8 & $?$ & 14 & 27 & 10 & 17 & 7.8 \\
\hline & 36131.31 & 24.9 & 2 & 3.1 & 17 & 6.3 & 10.7 & 7 & 14 & 29 & 11 & 18 & 7.9 \\
\hline & 36131.34 & 25.4 & $?$ & $?$ & 19.4 & 7.9 & 11.5 & $?$ & $?$ & 28 & 10 & 18 & 6 \\
\hline & 36131.37 & 31.2 & $?$ & $?$ & 21.5 & 7.6 & 13.9 & $?$ & $?$ & 28 & 10 & 18 & 9.7 \\
\hline & 36131.41 & 25.3 & 2 & 3.8 & 19.3 & 6.8 & 12.5 & 8 & 14 & 30 & 10 & 20 & 6 \\
\hline
\end{tabular}




\begin{tabular}{|c|c|c|c|c|c|c|c|c|c|c|c|c|c|}
\hline 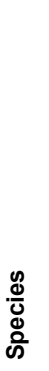 & 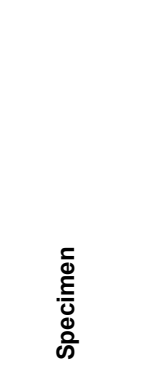 & 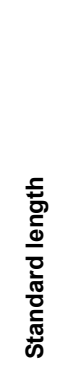 & 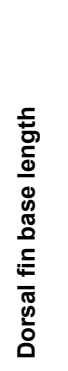 & 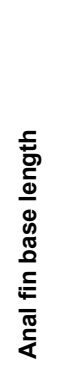 & 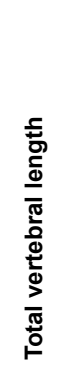 & 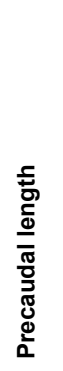 & 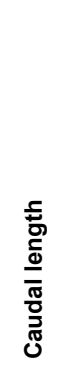 & 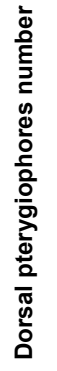 & 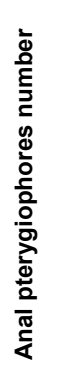 & 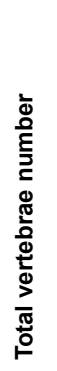 & 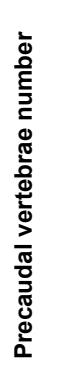 & 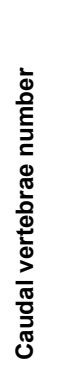 & 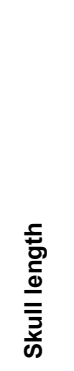 \\
\hline & 21396.1 & 25.4 & 2.6 & 3.7 & 18 & 6.2 & 11.8 & 8 & 14 & 29 & 10 & 19 & 7.4 \\
\hline & 21396.2 & 30.2 & 2.7 & 4.5 & 21.3 & 7.4 & 13.9 & 10 & 13 & 30 & 10 & 20 & 8.9 \\
\hline & 21396.3 & 22.8 & $?$ & 3.2 & 15.8 & 6.2 & 9.6 & $?$ & 14 & 30 & 11 & 19 & 7 \\
\hline & 21396.4 & 31.1 & 3.2 & 3.9 & 21.9 & 8.9 & 13 & 10 & 14 & 28 & 10 & 18 & 9.2 \\
\hline & 21396.5 & 38.8 & $?$ & 3.7 & 20.5 & 8.2 & 12.3 & $?$ & 14 & 30 & 10 & 20 & 18.3 \\
\hline & 21396.6 & 23.6 & 3.1 & 4 & 16.6 & 6.5 & 10.1 & 8 & 14 & 29 & 10 & 19 & 7 \\
\hline & 21396.7 & 23.1 & 2 & 3.3 & 17 & 6.5 & 10.5 & 8 & 14 & 30 & 10 & 20 & 6.1 \\
\hline & 21396.8 & 25.5 & $?$ & $?$ & 18.6 & 8 & 10.6 & $?$ & $?$ & 28 & 10 & 18 & 6.9 \\
\hline & 21396.10 & 21 & 2.8 & 3.4 & 18.6 & 6.8 & 11.8 & 12 & 14 & 28 & 10 & 18 & 2.4 \\
\hline & 21396.14 & 23.4 & $?$ & 3.7 & 16.8 & 6.1 & 10.7 & $?$ & 14 & 29 & 10 & 19 & 6.6 \\
\hline & 21396.15 & 23.5 & $?$ & 3.7 & 17.3 & 6.3 & 11 & $?$ & 14 & 29 & 10 & 19 & 6.2 \\
\hline & 21396.16 & 23.7 & 1.9 & 2.9 & $?$ & $?$ & 11.3 & 7 & 12 & $?$ & $?$ & 20 & $?$ \\
\hline & 21396.17 & 27.8 & 2.9 & 3.8 & 19.9 & 6.9 & 13 & 10 & 13 & 30 & 10 & 20 & 7.9 \\
\hline & P.4266.1 & 22.1 & $?$ & $?$ & $?$ & $?$ & 9.8 & $?$ & $?$ & $?$ & $?$ & 18 & $?$ \\
\hline & P.4266.2 & 23.8 & 2.5 & $?$ & 17.2 & 6.7 & 10.5 & 8 & $?$ & 31 & 11 & 20 & 6.6 \\
\hline & P.4266.3 & 25.3 & $?$ & 3.3 & 18.4 & 6.7 & 11.7 & $?$ & 14 & 30 & 10 & 20 & 6.9 \\
\hline & P.4266.5 & 19 & $?$ & $?$ & 13.5 & 5.4 & 8.1 & $?$ & $?$ & 29 & 11 & 18 & 5.5 \\
\hline & P.4266.6 & 27.2 & 2.1 & 3.7 & 21 & 8.5 & 12.5 & 8 & 14 & 31 & 12 & 19 & 6.2 \\
\hline & P.4266.11 & 23.9 & 2.2 & 3.3 & 17.2 & 5.9 & 11.3 & 10 & 12 & 30 & 10 & 20 & 6.7 \\
\hline & P.4266.12 & 24.5 & 2.5 & 3.6 & $?$ & $?$ & 11.5 & 9 & 12 & $?$ & $?$ & 19 & $?$ \\
\hline & P.4266.13 & 24.5 & 2 & 3 & 17.4 & 6.8 & 10.6 & 8 & 10 & 31 & 11 & 20 & 7.1 \\
\hline & P.4266.15 & 21.5 & 2.6 & 2.9 & 16.1 & 6.2 & 9.9 & 10 & 12 & 30 & 11 & 19 & 5.4 \\
\hline & P.4266.16 & 21.9 & $?$ & 2.7 & 15.5 & 5.5 & 10 & $?$ & 14 & 30 & 10 & 20 & 6.4 \\
\hline & P.4266.17 & 23.1 & $?$ & 3 & $?$ & $?$ & 11 & $?$ & 12 & $?$ & $?$ & 21 & $?$ \\
\hline & P.4266.18 & 24.2 & 2.5 & 3.7 & 17.3 & 6.6 & 10.7 & 8 & 14 & 29 & 10 & 19 & 6.9 \\
\hline & P.4266.19 & 26.8 & 2.5 & 3.2 & $?$ & $?$ & 12.5 & 8 & 12 & $?$ & $?$ & 19 & $?$ \\
\hline & P.4266.20 & 22.3 & 2 & 3.1 & 16.6 & 6.7 & 9.9 & 8 & 14 & 27 & 10 & 17 & 5.7 \\
\hline & P.4266.21 & 32 & 3.1 & 4.5 & 23.5 & 10 & 13.5 & 8 & 14 & 29 & 10 & 19 & 8.5 \\
\hline & P.4266.22 & 25.2 & 2.9 & 3.5 & 18.7 & 6.2 & 12.5 & 12 & 12 & 30 & 10 & 20 & 6.5 \\
\hline & P.4266.24 & 19.3 & 1.4 & 2.9 & 14.5 & 5.8 & 8.7 & 7 & 12 & 30 & 10 & 20 & 4.8 \\
\hline & P.4266.25 & 30.5 & 3.2 & 4.5 & 23.7 & 8.7 & 15 & 10 & 12 & 30 & 10 & 20 & 6.8 \\
\hline & P.4266.26 & 24 & $?$ & $?$ & 17.8 & 6.8 & 11 & $?$ & $?$ & 29 & 11 & 18 & 6.2 \\
\hline
\end{tabular}




\begin{tabular}{|c|c|c|c|c|c|c|c|c|c|c|c|c|c|}
\hline 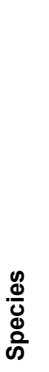 & 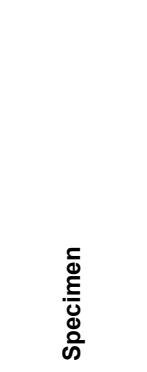 & 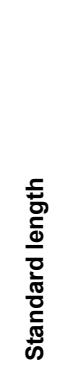 & 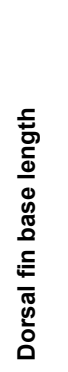 & 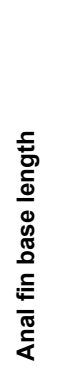 & 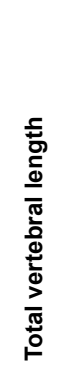 & 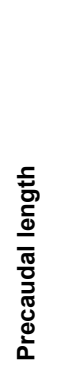 & 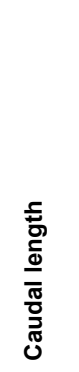 & 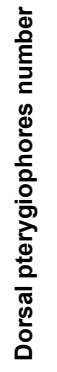 & 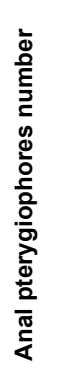 & 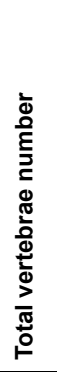 & 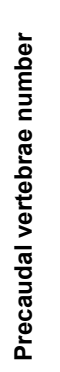 & 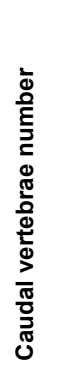 & 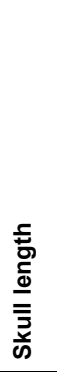 \\
\hline & P.4266.27 & 24 & $?$ & 2.6 & 16.9 & 7 & 9.9 & $?$ & 10 & 30 & 12 & 18 & 7.1 \\
\hline & P.4266.29 & 23 & $?$ & $?$ & $?$ & $?$ & 10.3 & $?$ & $?$ & $?$ & $?$ & 20 & $?$ \\
\hline & P.4266.30 & 24.4 & 2 & 2.7 & 16.9 & 6.1 & 10.8 & 8 & 10 & 29 & 11 & 18 & 7.5 \\
\hline & P.4266.31 & 24 & $?$ & 3.4 & 18.4 & 7 & 11.4 & $?$ & 14 & 31 & 11 & 20 & 5.6 \\
\hline & P.4266.32 & 28.2 & $?$ & 3.9 & 19.9 & 7.9 & 12 & $?$ & 14 & 29 & 10 & 19 & 8.3 \\
\hline & P.4266.33 & 28.9 & 2.9 & 3.1 & $?$ & $?$ & 12.7 & 8 & 10 & $?$ & $?$ & 18 & $?$ \\
\hline & P.4266.35 & 26.5 & $?$ & 3.3 & 18.2 & 6.6 & 11.6 & $?$ & 14 & 31 & 11 & 20 & 8.3 \\
\hline & P.4266.37 & 24.2 & 2.8 & 4.2 & 17 & 6 & 11 & 8 & 14 & 29 & 10 & 19 & 7.2 \\
\hline & P.4266.38 & 25 & 2.6 & 3.5 & 18.5 & 7 & 11.5 & 10 & 14 & 30 & 10 & 20 & 6.5 \\
\hline & P.4266.39 & 26.6 & 4 & 3.3 & 18.9 & 7 & 11.9 & 8 & 14 & 30 & 10 & 20 & 7.7 \\
\hline & P.4266.40 & 26.8 & 2 & 3.5 & 19 & 6.5 & 12.5 & 6 & 13 & 29 & 10 & 19 & 7.8 \\
\hline & P.4266.43 & 23.1 & 3 & 3.8 & 16.1 & 5.1 & 11 & 10 & 12 & 29 & 10 & 19 & 7 \\
\hline & P.4266.45 & 28.6 & 2.6 & 3.9 & $?$ & $?$ & 13.4 & 8 & 13 & $?$ & $?$ & 20 & $?$ \\
\hline & P.4266.46 & 24.1 & 2.1 & 2.5 & $?$ & $?$ & 11.2 & 8 & 10 & $?$ & $?$ & 19 & $?$ \\
\hline & P.4266.47 & 22.8 & 2.1 & $?$ & $?$ & $?$ & 10.3 & 8 & $?$ & $?$ & $?$ & 20 & $?$ \\
\hline & P.4266.48 & 23.5 & $?$ & 3.1 & $?$ & $?$ & 11 & $?$ & 13 & $?$ & $?$ & 20 & $?$ \\
\hline & P.4266.52 & 25.8 & $?$ & $?$ & 18 & 6.3 & 11.7 & $?$ & $?$ & 29 & 10 & 19 & 7.8 \\
\hline & P.4266.53 & 23.5 & 2.2 & 3.4 & 16.5 & 6.6 & 9.9 & 10 & 14 & 30 & 12 & 18 & 7 \\
\hline & P.4266.54 & 23.2 & $?$ & 3.5 & 16.3 & 6 & 10.3 & $?$ & 16 & 28 & 10 & 18 & 6.9 \\
\hline & P.4266.55 & 24.2 & $?$ & $?$ & 17.2 & 7 & 10.2 & $?$ & $?$ & 29 & 11 & 18 & 7 \\
\hline & P.4266.56 & 24 & $?$ & $?$ & 17.7 & 6.7 & 11 & $?$ & $?$ & 29 & 10 & 19 & 6.3 \\
\hline & P.4266.57 & 24.8 & $?$ & 3 & 18.1 & 7 & 11.1 & $?$ & 12 & 30 & 10 & 20 & 6.7 \\
\hline & P.4266.58 & 23.5 & 2.1 & 3.1 & 17.3 & 6.9 & 10.4 & 10 & 12 & 28 & 10 & 18 & 6.2 \\
\hline & P.4266.60 & 26.1 & $?$ & $?$ & $?$ & $?$ & 11.9 & $?$ & $?$ & $?$ & $?$ & 20 & $?$ \\
\hline & P.4266.61 & 24.2 & $?$ & 3.6 & $?$ & $?$ & 11.4 & $?$ & 12 & $?$ & $?$ & 20 & $?$ \\
\hline & P.4266.62 & 24.1 & 2.8 & 3.7 & $?$ & $?$ & 11 & 8 & 12 & $?$ & $?$ & 19 & $?$ \\
\hline & P.4266.65 & 22.7 & $?$ & $?$ & 17 & 6.5 & 10.5 & $?$ & $?$ & 30 & 11 & 19 & 5.7 \\
\hline & P.4266.66 & 30 & $?$ & 3.9 & 23.3 & 9.8 & 13.5 & $?$ & 12 & 29 & 10 & 19 & 6.7 \\
\hline & P.4266.69 & 28.5 & 2.7 & $?$ & 20.8 & 8 & 12.8 & 10 & $?$ & 29 & 10 & 19 & 7.7 \\
\hline & P.4266.71 & 26 & 2.8 & $?$ & 18.7 & 6.8 & 11.9 & 8 & $?$ & 30 & 11 & 19 & 7.3 \\
\hline & P.4266.72 & 22.5 & 2.5 & $?$ & $?$ & $?$ & 10.2 & 10 & $?$ & $?$ & $?$ & 20 & $?$ \\
\hline & P.4266.74 & 25.2 & 2.2 & 3 & 19.1 & 7.6 & 11.5 & 8 & 12 & 31 & 11 & 20 & 6.1 \\
\hline
\end{tabular}




\begin{tabular}{|c|c|c|c|c|c|c|c|c|c|c|c|c|c|}
\hline 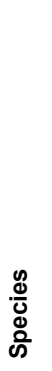 & 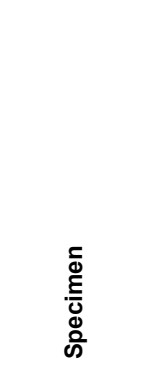 & 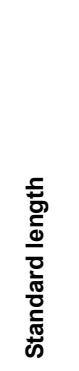 & 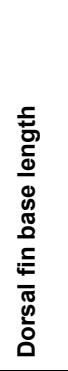 & 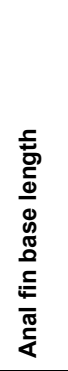 & 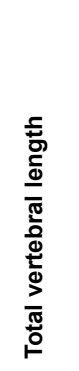 & 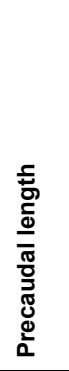 & 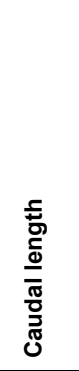 & 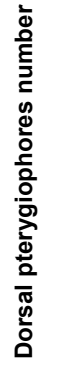 & 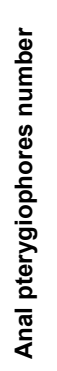 & 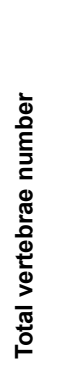 & 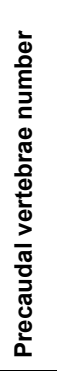 & 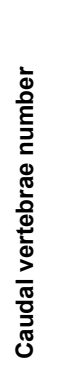 & 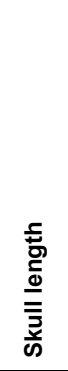 \\
\hline & P.4266.75 & 32.1 & 2.4 & 3.5 & 24.4 & 9.8 & 14.6 & 8 & 14 & 30 & 11 & 19 & 7.7 \\
\hline & P.4266.76 & 26.7 & 4.2 & 3.4 & 19.3 & 7.3 & 12 & 9 & 14 & 31 & 11 & 20 & 7.4 \\
\hline & P.4266.77 & 24.1 & 1.8 & $?$ & 17.9 & 6.5 & 11.4 & 7 & $?$ & 30 & 11 & 19 & 6.2 \\
\hline & P.4266.78 & 25.5 & 2.5 & 3.6 & 18 & 6.7 & 11.3 & 10 & 13 & 30 & 11 & 19 & 7.5 \\
\hline & P.4266.79 & 25.8 & 1.8 & 2.9 & 19.2 & 7 & 12.2 & 8 & 10 & 30 & 10 & 20 & 6.6 \\
\hline & P.4266.80 & 25.2 & $?$ & 3.1 & 18.7 & 7.1 & 11.6 & $?$ & 14 & 31 & 11 & 20 & 6.5 \\
\hline & P.4266.82 & 24.5 & 1.6 & 3.2 & 17.3 & 7 & 10.3 & 6 & 14 & 30 & 11 & 19 & 7.2 \\
\hline & P.4266.84 & 32 & 3 & 4.1 & 23.3 & 8.5 & 14.8 & 8 & 12 & 31 & 11 & 20 & 8.7 \\
\hline & P.4266.85 & 30 & 3.2 & 5.6 & 21.1 & 8.1 & 13 & 8 & 14 & 29 & 11 & 18 & 8.9 \\
\hline & P.4266.87 & 20.7 & 1.9 & 2.6 & 15.7 & 5.9 & 9.8 & 8 & 12 & 30 & 10 & 20 & 5 \\
\hline & P.4266.88 & 26.8 & 2.9 & 3.7 & 19.8 & 7.8 & 12 & 8 & 12 & 31 & 11 & 20 & 7 \\
\hline & P.4266.89 & 24 & 2.5 & 3 & 17 & 6.5 & 10.5 & 10 & 12 & 28 & 10 & 18 & 7 \\
\hline & P.4266.95 & 24.2 & 2.5 & 3.4 & 18.1 & 7.3 & 10.8 & 10 & 14 & 31 & 11 & 20 & 6.1 \\
\hline & P.4266.96 & 33.2 & 3.2 & 4.3 & 23.1 & 9 & 14.1 & 10 & 12 & 30 & 10 & 20 & 10.1 \\
\hline & P.4266.97 & 23.5 & 2 & 3.1 & $?$ & $?$ & 11.3 & 8 & 14 & $?$ & $?$ & 19 & $?$ \\
\hline & P.4266.98 & 22.8 & 2.1 & 3 & 16.2 & 5.7 & 10.5 & 8 & 12 & 29 & 10 & 19 & 6.6 \\
\hline & P.4266.100 & 25.8 & 2.4 & 4.5 & 18 & 6.8 & 11.2 & 10 & 13 & 30 & 10 & 20 & 7.8 \\
\hline & P.4266.101 & 26.1 & 2.2 & 3.8 & 20.3 & 8.2 & 12.1 & 8 & 15 & 31 & 11 & 20 & 5.8 \\
\hline & P.4266.102 & 23.1 & 1.7 & 3.4 & 16.7 & 6.2 & 10.5 & 8 & 14 & 29 & 10 & 19 & 6.4 \\
\hline & P.4266.104 & 30 & 3.1 & 5 & $?$ & $?$ & 14.2 & 10 & 14 & $?$ & $?$ & 20 & $?$ \\
\hline
\end{tabular}

